\title{
Property of stocks and wealth effects on consumption
}

\author{
RICARDO M. SOUSA ${ }^{\dagger}$ \\ University of Minho - Department of Economics \\ Campus of Gualtar, 4710 - 057 - BRAGA - PORTUGAL \\ E-mail: rjsousa@eeg.uminho.pt
}

March 2003

\begin{abstract}
Recent fluctuations of financial markets, especially, stock markets fluctuations, have revived the interest concerning the dynamics of real economic activity, namely, of private consumption.

In this work, the role of stock market as a determinant of private consumption is analyzed, namely, by the consideration of wealth effects. It is also analyzed the potential differences of these effects originated by different categories of property of stocks (direct versus indirect property).

Using a sample for the U. S. economy, in the period 1952:Q1 - 2001:Q4, several long-run relationships were estimated, suggesting that wealth effects associated to direct property are about 3.5 times superior to those associated to indirect property. Short-run dynamics is analyzed with the estimation of a single equation, suggesting that consumption contemporaneously answers to changes in income and in wealth and that the adjustment to long-run component is very slow, which constitutes an indicator that consumers gradually change their behaviors, possibly, due to habit formation. There is also evidence supporting the presence of the indirect channel of wealth effect.
\end{abstract}

Key-words: stock market, wealth, consumption, cointegration

JEL classification: E21, E44, D12

\footnotetext{
${ }^{\dagger}$ The author is extremely grateful to Prof. Dolores Cabral and Prof. Vasco Gabriel for hepful comments.
} 


\section{Property of Stocks and Wealth Effects on Consumption}

\section{Introduction}

Consumption is an extremely important component of aggregate demand, not only because of its influence on economic growth, but also in the determination of the economic cycles. The study of private consumption decisions is, therefore, relevant.

Conventional macroeconomic analysis includes the wealth effect in models of product, income and prices determination, namely, considering that wealth influences not only private consumption, but also money demand, in the general context of assets' choice.

In the life cycle and permanent income' models and their recent developments, consumer's wealth is a fundamental argument. On one side, private consumption is a function not only of disposable income, but also of net wealth. By the other hand, a wealth increase pushes money demand, so that agents can maintain the desired proportion between money and other categories of wealth.

With the recent growth of relative importance of financial assets, especially of stocks, in the net wealth' composition, research has been characterized by the introduction of important features that involve the behavior of financial markets, namely of stock markets, in the theories of the consumption decision. In fact, financial markets influence macroeconomic behavior, mainly, through their impact on consumption and investment. Additionally, consumption and investment generate important feedback effects on financial markets.

The question to know how financial wealth influence consumption behavior became, recently, more pressing, because of the increasing fears that substantial fluctuations in financial markets, especially, in the stock market, could cause great fluctuations on consumption demand and therefore on aggregate demand, with the possibility of generating episodes of economic recession.

Theoretical analysis in this area is still not gathering consensus and empirical evidence is still inconclusive.

Among the empirical studies that find the evidence of significant wealth effects on consumption, we should refer: Mankiw and Zeldes (1991), Barrell and In't Veld (1992), Ogawa et al. (1996) and Ludvigson and Steindel (1999). Mankiw and Zeldes (1991) show that stockholders' consumption is more volatile and more strongly 
correlated with stock market returns than non-stockholders' consumption. Barrell and In't Veld (1992) develop a macroeconomic model that includes long-run government's budget constraint and presupposes weak form of solvability and conclude that wealth effects are important in any model that is intended to be useful in the analyzing of the effects of the adoption of economic policies. ${ }^{1}$ Ogawa et al. (1996) conclude that net financial wealth is a significant explanatory variable of consumption and show that changes of net wealth were responsible for about a third of the total change of consumption, during the economic boom of the eighties in Japan. Ludvigson and Steindel (1999) also identify a significant stock market wealth effect on consumption expenditure in U.S.A., although they sustain that the behavior of this market is not a good indicator of future consumption.

By the other hand, Poterba and Samwick (1995), Starr-McCluer (2002), Otoo (1999) and Poterba (2000) find modest wealth effects. Poterba and Samwick (1995) show that, although the patterns of stocks property have changed in the last years, these changes didn't have a significant impact on the relation between the fluctuations of the stock prices and the private consumption. Starr-McCluer (2002) suggests that concerns relative to trend inversions of the stock prices can lead stockholders not to spend realized gains. Otoo (1999) shows that the correlation between the stock prices and the consumer confidence level (either stockholder, or non-stockholder) doesn't change with the property of stocks, which means that consumers use stocks, mainly, as a leading indicator of real economic activity. Poterba (2000) points out that, on one side, the concentrated nature of wealth and, on the other, the desire to leave bequests and precautionary motives in the consumer's behavior constitute important possible causes of the modest wealth effects.

This lack of consensus is, partly, the mirror of the use of different measures in order to delimit the wealth concept, but also of alternative methodologies, adopted to quantify the wealth effects generated by stock market on private consumption.

On the other hand, although literature emphasize that the impact on private consumption of different categories of assets can be different ${ }^{2}$, the question to know if there are differences of magnitude between wealth effects originated by direct property of stocks and those originated by indirect property, hadn't yet been addressed. A priori,

\footnotetext{
${ }^{1}$ Blanchard et al. (1991) distinguish two types of solvability of public accounts: (i) the strong form, which requires that the present value of future deficits and surplus, including interest payments, as a percentage of GDP, sum zero; and (ii) the weak form, which requires that the ratio debt/income is constant over time. ${ }^{2}$ See, for example, Zeldes (1989b) e Poterba e Samwick (1995).
} 
we would expect that wealth effects originated by direct property of stocks are more significant, because direct property requires a permanent search for information from the stockholder, in order to match the evolution of market prices and, consequently, it provides a larger perception of wealth changes.

The main goal of this work is to analyze the impact of stock market on the behavior of private consumption, namely, disaggregating wealth effect in its components associated to direct and indirect property of stocks.

In the first part, we briefly describe the evolution of wealth composition in U.S.A. (point 1); then, we review the theoretical literature and empirical evidence concerning the subject (point 2); in the second part, after having presented methodology (point 3), and using a sample for the U.S. economy for the period 1952-2001, we estimate a model that captures the effect of stock market on private consumption decisions (point 4).

The adopted methodology implies the use of the estimation of two relationships: a long-run relationship, specified to determine the magnitude of the impact of changes in the stock of wealth, namely, those associated to fluctuations in financial markets and their components on private consumption; a short-run relationship, defined to explain the dynamics of the adjustments of private consumption to the variables that are its determinants. Then, we describe data, as well as sources of information. Finally, the model is estimated, the results are presented and major conclusions are explained. Using a sample of quarterly data for the U.S. economy for the period 1952:Q1 - 2001:Q4, it is shown that wealth effects associated to direct property of stocks are 3.5 times superior to those associated to indirect property. The short-run dynamics suggests that consumption answers contemporaneously to income and wealth changes and that the adjustment to long-run component is very slow, probably, due to habit formation. There is also evidence supporting the presence of the indirect channel of wealth effect.

\section{Evolution of wealth composition in U.S.A.}

According to Poterba (2000), the stock market represents approximately one fourth of total net worth in U.S.A.. Ludvigson and Steindel (1999) refer that the second half of the nineties was characterized by substantial changes in the households' composition of wealth, mainly due to movements in the stock market. Bertaut and StarrMcCluer (2000) analize the U.S. households' composition of assets and liabilities and show that over the past 15 years, despite the great diversification of financial products, 
the portfolio of the typical household is still very simple and safe, consisting of checking accounts, savings accounts and retirement accounts. Additionally, they emphasize the concentrated nature of the property of stocks. ${ }^{3}$

Using data from the Flow of Funds Accounts ${ }^{4}$ and published by the Board of Governors of Federal the Reserves System, we present in Annex I the major features of the evolution of financial wealth composition of households and nonprofit organizations in the USA.

When we analyze the behavior of net wealth (Figure 1), it is notorious the more pronounced growth, starting by the middle of the nineties. Additionally, financial assets represent the largest proportion of assets, that is, about $70 \%$, a position that is, substantially, reinforced in that period.

The data also reveal that the composition of financial assets has changed significantly, with the decrease of the relative importance of deposits and the growth of equities, investment funds and pension funds, these representing, actually, the major financial asset. Therefore, there is a greater exposure of households and nonprofit organizations to financial markets, either through direct property, or indirect property.

Figure 1 - Evolution of wealth of households and nonprofit organizations in the USA.
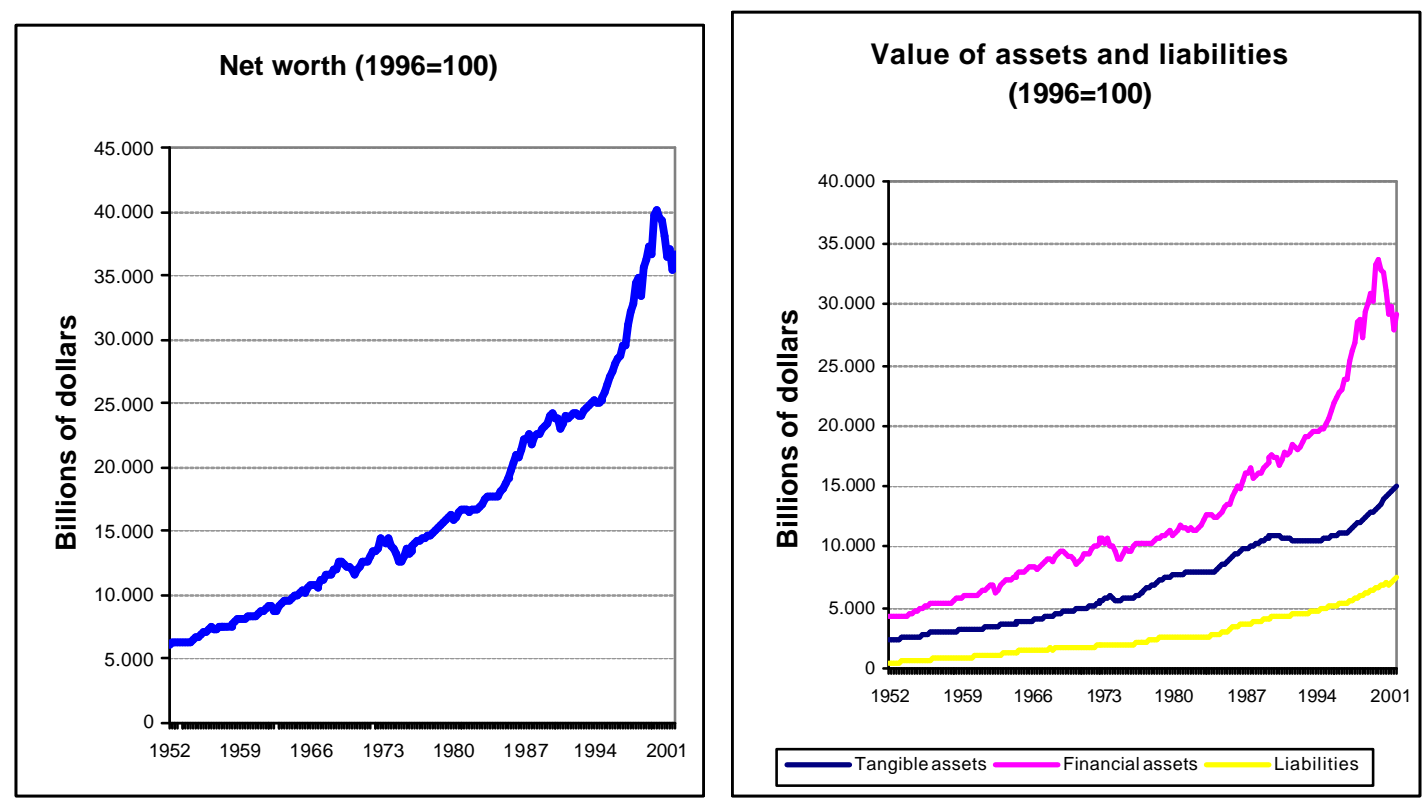

Source: Flow of Funds Accounts, Board of Governors of Federal Source: Flow of Funds Accounts, Board of Governors of Federal Reserve System; author's calculus.

Reserve System; author's calculus.

\footnotetext{
${ }^{3}$ The authors refer that, in 1998 , less than a half of the households owned stocks.

${ }^{4}$ Flow of Funds Accounts is a U.S. quarterly publication (Z.1 release) that comprises macroeconomic information, which is released in the second week of the March, June, September and December by the Board of Governors of the Federal Reserve System. It provides information concerning the composition of GDP, National Income and wealth, the growth of debt and consumer credit by different groups of economic agents and by financial instrument, in value and in flows. It also presents an estimate of different measures of private saving.
} 
On the other hand, as we can see in Figure 2, the wealth-income ratio and savings rate are negatively related since the middle of the nineties, which can be thought as an indicator of a robust wealth effect in this period.

Figure 2 - Evolution of wealth-income ratio and savings rate of households and nonprofit organizations in USA.
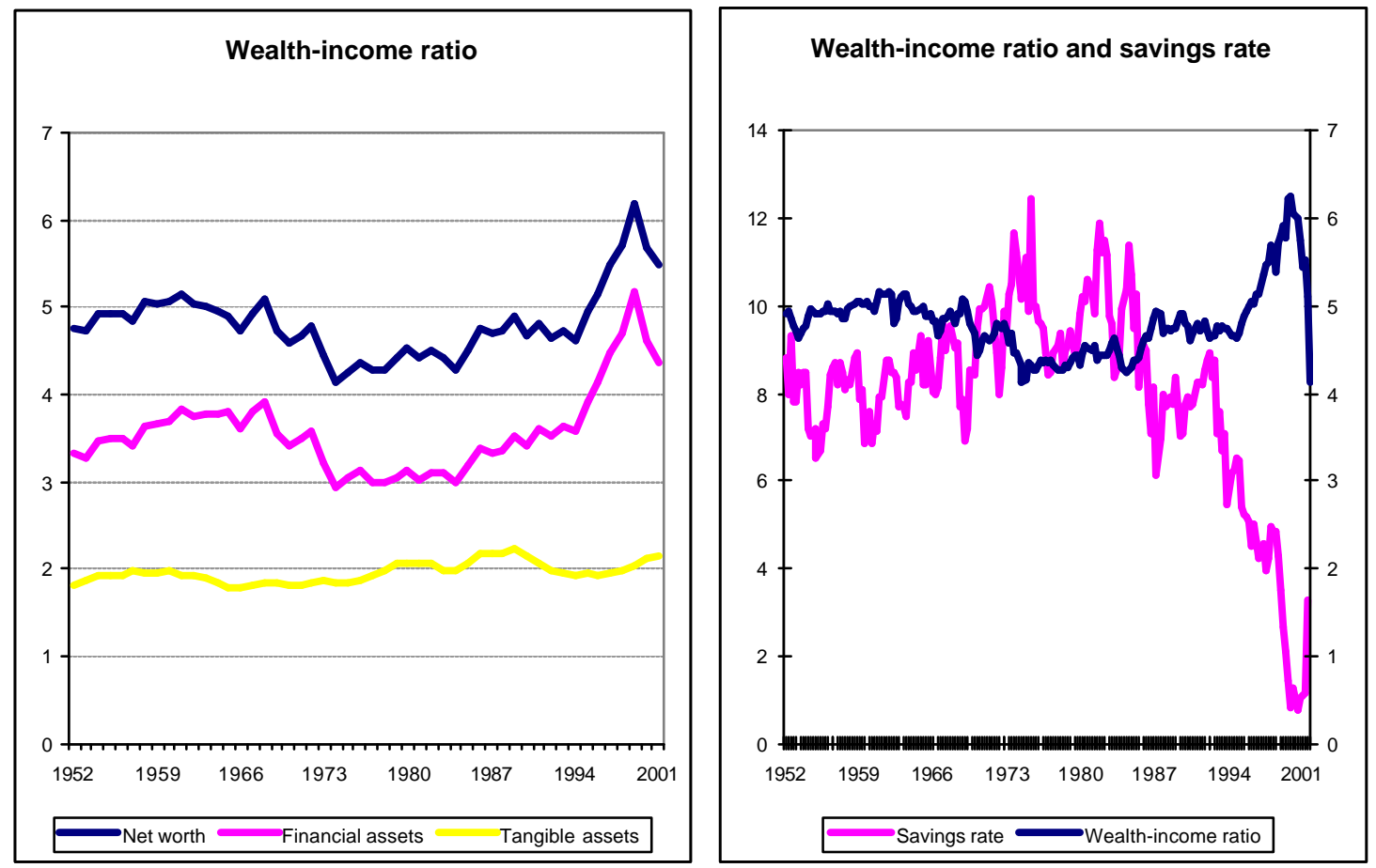

Source: Flow of Funds Accounts, Board of Governors of Federal Source : Flow of Funds Accounts, Board of Governors of Federal Reserve System; author's calculus.

Reserve System; U.S. Department of Commerce, Bureau of Economic Analysis; author's calculus.

We move now to a brief review of the literature concerning the existence of wealth effects on consumption.

\section{A Brief Review of Literature}

During last years, stock markets in the largest economies of OECD showed great fluctuations. Simultaneously, the property of stocks increased substantially. The combination of these developments and, in particular, the recent volatility of financial markets has stimulated the interest for the potential impact of great movements in the stock prices on real economic activity.

According to Boone et al. (1998), the fluctuations in the stock prices influence economic activity through, at least, three channels: increasing the prices of assets, the cost of capital decreases and, therefore, investment demand increases; the credit 
channel, that tends to be influential because of the increase of the value of the collateral (which reduces the problem of the adverse selection) and the reduction of the risk associated to profitable investments; and the wealth effect channel.

The theoretical mechanisms associated to the wealth effect are well-known: as the financial assets-income ratio increases, consumption of stockholders becomes more sensitive to changes in the prices of assets (Mankiw and Zeldes, 1991); and, as indirect property of stocks increases - through mutual or pension funds -, the correlation between the growth of consumption and the fluctuations of stock market increases (Poterba and Samwick, 1995).

Dynan and Maki (2001) distinguish two types of wealth effects: the direct channel and the indirect channel.

The logic underlying a wealth effect is quite simple: an increase in the price of stocks boosts wealth and, therefore, allows an increase in consumption, for the same income level. If this answer emerges in a relatively quick way, the relationship between stock market and consumption behaviors can be referred as the direct channel and it is graphically identified by the negative correlation between the savings rate and the wealth-income ratio. ${ }^{5}$

When the answer of consumption happens with a significant temporary lag, there is uncertainty concerning the persistence of the movement in the stock market and it becomes difficult to determine the extension of indirect property of stocks, for example, through pension funds. In fact, the lag can be so great that wealth effect is not revealed in current consumption of stockholders, but just when the assets are transferred to future generations through bequests. ${ }^{6}$ In these circumstances, the aggregate relation between stock market wealth and consumption can exist, because, for example, changes in the stock prices signal future changes in income - this is called the indirect channel.

The first tests to the life cycle model (Ando and Modigliani, 1963; Modigliani, 1971; Modigliani and Tarantelli, 1975) showed that the consumer's wealth had a significant impact on consumption, with a wealth increase of 1 dollar contributing to the

\footnotetext{
${ }^{5}$ If $\Delta C^{*}=-\Delta S^{*}=p m c \Delta W$, with $C^{*}$, the target consumption, $S^{*}$, the target savings, $W$, the wealth e $p m c$, the marginal propensity to consume wealth, then $\Delta(S / Y)^{*}$ is approximately equal to $p m c \Delta(W / Y)$, with $Y$ representing income.

6 The impact on consumption of a change in stock market wealth depends on its cause: an increase originated by higher expected profits turns out budgetary constraint; an increased associated to a decrease in the discount rate changes the slope of budgetary constraint. Dynan and Maki (2001) analyze the average answer of consumption over time. Consumers can also decide to reduce labor supply and to consume more leisure instead of consuming more: Cheng and French (2000) indicate the wealth effect as a determinant of the relatively small increase in the rate of partic ipation in labor market.
} 
increase of consumption approximately 6 cents (a marginal propensity to consume wealth that varied between $4 \%$ and $8 \%$ ). However, as Pearce refers $(1983$, p. 15), these works didn't work, directly, with the question of knowing if capital gains increase consumption, since wealth was not disaggregated by category of assets.

Two related studies for the U.S. economy, for the period comprised between Second World War and the beginning of sixties, showed contradictory conclusions: Arena (1965) noted that capital gains don't have a significant effect on consumption ${ }^{7}$, suggesting that this is the result of the strongly biased distribution of stocks and that the wealthier households aren't influenced by fluctuations of stock market when they take a consumption decision; Bhatia (1972) concluded for the existence of a significant impact of capital gains and showed, additionally, that realized gains have a substantially larger effect than potential gains. Some differences among these studies can explain these results: the first analysis included, in the consumption definition, the purchase of durable consumption goods, while the second considered just an estimate of the services provided by these goods; and the second study used a broad measure of capital gains and, simultaneously, considered a larger lag concerning theirs effects on consumption.

The following works found a positive relationship between capital gains and consumption. Bosworth (1975) showed that the expenditures in non-durable consumption of goods and services are strongly related with movements in the stock prices, but the same doesn't happen with purchases of durable consumption goods. It is also suggested that consumers consider the average capital gains when taking consumption decisions, instead of considering just current gains. The same relationship was found by Elliott (1980).

While first studies included, directly, capital gains in the consumption function, recent studies are centered in models based on wealth ${ }^{8}$ Empirical estimates are quite varied. Mayer and Simons (1994) present a representative group of estimates ${ }^{9}$,

\footnotetext{
${ }^{7}$ Evans (1967) reaches the same result, although emphasizing that wealth can play an important role in the determination of consumption function in periods of economic depression..

${ }^{8}$ See, for example, Laumas and Ram (1982) that suggest that wealth is a variable that should be explicitly included on consumption function. The authors show, additionally, that wealth effects associated to nonhuman wealth are greater than those associated to human wealth.

9 The authors consider four components of consumption: non-durable consumption goods, durable consumption goods, (with the exception of automobiles), durable consumption goods and services of consumption. Consumption is then modeled as a function of labor income, property income and transfers, of the market value of stocks and other categories of wealth. The estimates suggest that the increase of 1 dollar in the value of equities contributes to the increase of consumption in 2 cents, while a similar increase in non-stock market wealth ncreases consumption in 1.4 cents. The long-run impact of an increase of 1 dollar in the non-stock market wealth is of 6.1 cents.
} 
suggesting that the long-run impact of the increase of 1 dollar in stock market wealth contributes to the increase of consumption approximately 4.2 cents. Brayton and Tinsley (1996) obtain similar results. ${ }^{10}$ Caporale and Williams (1997) suggest a marginal propensity to consume wealth comprised between $3 \%$ and $5 \%$, pointing out that the processes of financial liberalization/deregulation observed in the last years have contributed to strengthen wealth effects. Ludvigson and Steindel (1999) also find a positive relation between changes in wealth and consumption, although they point out that the effect is unstable over time. ${ }^{11}$ Poterba (2000) suggests that marginal propensity to consume the shocks on wealth (namely, on stock market over nineties) can be smaller than the estimated. Nevertheless, the author concludes that even with relatively small estimates for the marginal propensity to consume wealth, the effects on consumption of the stock market boom would be substantial. Mehra (2001) suggests that wealth effect is independent from the category of wealth - an increase of 3 cents on consumption for each dollar of increase on wealth - and that there is a lag in the answer of consumption. By the other way, Desnoyers (2001) considers that wealth effect is temporary and relatively fast, suggesting a marginal propensity to consume stock market wealth approximately $5.8 \%$.

At the international level, evidence is also quite diversified. In Japan, Mutoh et al. (1993) and Ogawa (1992) suggest estimates for the marginal propensity to consume wealth around 1\%. Horioka (1996) and Ogawa et al. (1996) present estimates around $4 \%$, varying, considerably, with the definitions of wealth and income. In France, several studies (Bonner and Dubois, 1995; Grunspan and Sicsic, 1997) haven't found evidence of a wealth effect. In Italy, Rossi and Visco (1995) present evidence of a marginal propensity to consume wealth of between $3 \%$ and $3.5 \%$, when Social Security's transfers are considered in the definition of disposable income. In Australia, Tan and Voss (2000) estimate that the increase of 1 dollar in per capita wealth will be eventually related with the annual increase of non-durable consumption goods approximately 4 cents. Additionally, the authors don't find evidence that the deregulation and the liberalization processes have had significant effects on the growth of the consumption.

\footnotetext{
${ }^{10}$ The authors suggest that marginal propensity to consume stock market wealth $(3 \%)$ is less than that associated to different categories of wealth $(7.5 \%)$.

${ }^{11}$ Using data for the U.S. economy, the authors estimate the equation of Modigliani (1971) - which related consumption expenditure with disposable income and wealth -, but disaggregate wealth in two categories: one related with stock market and the other for different assets. They show that the stock market wealth effect is sensible to the sample period and it was greater, mainly, in the last years of the seventies and the beginning of the eighties. However, marginal propensity to consume stock market wealth is unstable and, therefore, this parameter is uncertain.
} 
Pichette (2000) suggests, for Canada, the existence of a wealth effect of the order of $3 \%$. Finally, Marry et al. (2001) they analyze a panel of 14 countries of OCDE and they verify the modest existence of wealth effects.

In sum, as Boone et al. (1998, p. 13) refer, the wealth effect is generally larger for the USA than for other countries of the G7 economies.

\section{Methodology}

The adopted methodology consists of two stages.

First, a long-run relation (steady-state relation) between consumption and wealth is estimated. We apply ADF tests (Augmented Dickey-Fuller tests) to determine the existence of unit roots and, then, to determine the existence of cointegration, using Engle and Granger (1987) methodology. We use the Stock and Watson (1993) procedure to estimate the long-run relation.

In the second stage, we proceed with the analysis of short-run dynamics, that is, the analysis of how consumption reacts to shocks on wealth and how these deviations from long-run relation are corrected. We use a single equation.

\subsection{Long-run relation}

Following Davidson and Hendry (1981), Blinder and Deaton (1985), Macklem (1994), Boone et al. (1998), Ludvigson and Steindel (1999), Pichette (2000) and Tan and Voss (2000), Davis and Palumbo (2001) and Mehra (2001), among others, we defined models that incorporate a long-run relation (steady-state) between consumption, wealth (and its different components) and income.

The long-run relationships were based, fundamentally, in the permanent income hypothesis developed by Friedman (1957) and retaken by the studies of Hall (1978, 1988), Flavin (1981) and Campbell (1987). According to this hypothesis, consumption is a function of human wealth (after-tax labor income) and non-human wealth (tangible wealth and financial wealth). In the case of financial wealth, it is still possible to disaggregate this variable, because the impact on consumption of different assets' categories can be different (Zeldes, 1989; and Poterba and Samwick, 1995).

The specification of the models to estimate includes, additionally, the disaggregating of stock market wealth in two components: direct property and indirect 
property of stocks. The goal is to analyze the existence of potential differences of the wealth effects originated by each one of these wealth components.

The estimated long-run relations were the following ones:

$$
\begin{gathered}
c_{t}=\beta w_{t}+\delta y_{t}+\sum_{i=-k}^{k} \beta_{i} \Delta w_{, t+i}+\sum_{i=-k}^{k} \delta_{i} \Delta y_{, t+i}+u_{1 t} \\
c_{t}=\alpha s t w_{t}+\theta n s t w_{t}+d y_{t}+\sum_{i=-k}^{k} \alpha_{i} ? s t w_{, t+i}+\sum_{i=-k}^{k} \theta_{i} ? n s t w_{, t+i}+\sum_{i=-k}^{k} d_{i} ? y_{, t+i}+u_{2 t} \\
c_{t}=\gamma s t w d_{t}+\varphi s t w i_{t}+\theta n s t w_{t}+\delta y_{t}+\sum_{i=-k}^{k} \gamma_{i} \Delta s t w d_{t+i}+\sum_{i=-k}^{k} \varphi_{i} \Delta s t w i_{t+i}+\sum_{i=-k}^{k} \theta_{i} \Delta n s t w_{t}+ \\
+\sum_{i=-k}^{k} \delta_{i} \Delta y_{t+i}+u_{3_{t}}
\end{gathered}
$$

where $c$ denotes private consumption expenditures, $w$, net wealth of private sector, stw, stock market wealth, stwd, wealth directly detained in the form of stocks, stwi, wealth indirectly detained in the form of stocks, nstw, non-stock market wealth, $y$, after-tax labor income, $u_{1 t}, u_{2 t}$ and $u_{3 t}$, respectively, the disturbance terms of equations (1), (2) and (3) and the operator $\Delta$ represents first-order differences. All variables (dependent and explanatory) are valued at constant prices and expressed in the logarithmic form of per capita terms. The $\beta, \alpha, \gamma, \varphi, \theta$ parameters represent, respectively, the long-run elasticities of consumption in order to aggregate net wealth, to stock market wealth, to wealth directly detained in the form of stocks, to wealth indirectly detained in the form of stocks, to non-stock market wealth and to after-tax labor income and if the explanatory variables are integrated of order 1 and the resulting error terms of the regression of the dependent variable on the explanatory variables are integrated of order 0 (that is, stationary) then, the time-series will be cointegrated and it is possible to define, respectively, for each equation, the cointegration vectors $(1,-\beta,-\delta),(1,-\alpha,-\theta$, $\delta)$ and $(1,-\gamma,-\varphi,-\theta,-\delta)$.

Equation (1) presupposes the existence of a long-run relation between consumption, net wealth and income; equation (2) presupposes the same relation, but disaggregates net wealth in stock market wealth and non-stock market wealth; finally, equation (3) disaggregates stock market wealth, distinguishing direct property of stocks 
and indirect property of stocks. We must notice that, as it was previously referred, although the literature emphasizes that the impact on consumption (of the different assets' categories) can be different, the question of knowing if wealth effects originated by direct property of stocks are of the same magnitude of those originated by indirect property of stocks wasn't still addressed, which we intend to analyze through the equation (3).

The models will be estimated using DOLS (dynamic ordinary least squares)' method, proposed by Saikkonen (1991) and Stock and Watson (1993), with the goal of eliminating regressors' endogeneity on the distribution of the least squares estimators. When we detect the presence of heterokedasticity in the estimation with DOLS, we use robust standard errors, suggested by Newey and West (1987). Finally, when, after the estimation using Stock and Watson (1993) procedure, we detect serial autocorrelation, the long-run relations will be estimated using DGLS (dynamic generalized least squares)' method, suggested by Stock and Watson (1993).

It is still important to point out three aspects of the specification of models, which are related with the nature of consumption, wealth and income data. The first is that economic literature point out that different categories of assets have different impacts on consumption - therefore, the estimation of long-run relations (1), (2) and (3). The second is that explanatory theories of consumption behavior typically refer the flow of consumption' expenditures so, therefore, we exclude durables consumption expenditure, because this is just the replacement and, eventually, the increase of the existing stock, and not the flow of services that the existing stock of goods provides. Consequently, we consider only the flow of expenditure with the aquisition nondurable goods and services. Finally, the inclusion of variables in the logarithmic form doesn't allow per se the consideration of the impact of each additional dollar of wealth (or of one of its components) on private consumption, but just the elasticity of this in order to that. For this reason, the models will also be estimated with the variables in levels to allow for estimates of marginal propensities to consume.

\subsection{Short-run dynamics}

Specifications (1), (2) and (3) allow us to determine the equilibrium level for consumption as a function of wealth and income, as well as to obtain estimates of different marginal propensities to consume. The long-run relations (estimated as cointegration vectors) can, then, be included as error-correction terms in dynamic 
equations that explain consumption's short-run fluctuations. These include, besides the error-correction terms, lagged values of variables included in long-run specifications and they can still be enriched with a vector of other variables, namely: the interest rate to reflect substitution effects; the inflation rate, as a proxy for the uncertainty, as well as for the assets depreciation; the unemployment rate, as a proxy for the uncertainty concerning future flows of income; the confidence index, to reflect the level of consumers' optimism/pessimism; the budget surplus, to reflect possible constraints of public sector on private sector; the Current Accounts surplus, to reflect possible constraints of external sector on private sector; and the rate of growth of GDP, as a proxy for the existence of habit formation. ${ }^{12}$

From the long-run relations, the following dynamic equations were specified:

$$
\begin{aligned}
\Delta c_{t}= & \mu+\lambda e c t_{t-1}+\sum_{i=1}^{k} \chi_{i} \Delta c,_{t-i}+\sum_{i=0}^{k} \kappa_{i} \Delta w_{, t-i}+\sum_{i=0}^{k} \omega_{i} \Delta y_{, t+i}+\sum_{i=1}^{k} \vartheta_{i} \Delta z,_{t-i}+e_{1_{t}} \\
\Delta c_{t}= & \mu+\lambda e c t_{t-1}+\sum_{i=1}^{k} \chi_{i} \Delta c,_{t-i}+\sum_{i=0}^{k} \psi_{i} ? s t w_{, t-i}+\sum_{i=0}^{k} \xi_{i} ? n s t w_{, t-i}+\sum_{i=0}^{k} \omega_{i} ? y_{, t-i}+ \\
& +\sum_{i=1}^{k} \vartheta_{i} \Delta z,_{t-i}+e_{2 t} \\
\Delta c_{t}= & \mu+\lambda e c t_{t-1}+\sum_{i=1}^{k} \chi_{i} \Delta c,_{t-i}+\sum_{i=0}^{k} v_{i} \Delta s t w d_{t-i}+\sum_{i=0}^{k} \eta_{i} \Delta s t w i_{, t-i}+\sum_{i=0}^{k} \xi_{i} \Delta n s t w_{t,-i}+ \\
& +\sum_{i=0}^{k} \omega_{i} \Delta y_{, t-i}+\sum_{i=1}^{k} \vartheta_{i} \Delta z,_{t-i}+e_{3 t}
\end{aligned}
$$

where $z$ is a vector of variables that, potentially, determines the short-term consumption dynamics, but that economic literature doesn't attribute any role in explaining the longrun relation and ect is the error-correction term (cointegration equation or long-run component), which can be expressed for equations (1 '), (2') and (3'), respectively, as:

$$
\begin{aligned}
& e c t_{t-1}=c_{t-1}-\hat{\beta} w_{t-1}-\hat{\delta} y_{t-1} \\
& e c t_{t-1}=c_{t-1}-\hat{\alpha} s t w_{t-1}-\hat{\theta} n s t w_{t-1}-\hat{\delta} y_{t-1} \\
& e c t_{t-1}=c_{t-1}-\hat{\gamma} s t w d_{t-1}-\hat{\varphi} s t w i_{t-1}-\hat{\theta} n s t w_{t-1}-\hat{\delta} y_{t-1} .
\end{aligned}
$$

\footnotetext{
${ }^{12}$ See, for example, Masson et al. (1996).
} 
They are, therefore, used as the estimated cointegration coefficients in equations (1), (2) and (3).

Intuitively, the parameter associated to the error-correction term in the dynamic equations should have a negative sign, since, when in a certain period of time consumption moves away from its equilibrium value, this deviation should be corrected in the following periods; the greater the value is, the faster will be the correction of the deviation and, therefore, the return to the equilibrium value. Dynamic equations (1'), (2') and (3') are, then, estimated by OLS.

Finally, it's important to point out that in this work, we estimate short-period dynamics using a single equation, instead of considering the estimation of a system of equations, typically, designated as autoregressive vectors as it happens, for example, in Ludvigson and Steindel (1999). This means that not only we ignore possible feedback effects between variables of long-run component, but also the possibility that wealth and income equations - and not just consumption equation - could contain additional information concerning long-period component and, therefore, concerning short-period dynamics.

\section{Estimation and results}

In this section, after describing the sample, we estimate models ${ }^{13}$ and analyze results, pointing out their differences from theoretical and empirical literature.

\subsection{Data}

The sample used in the estimation of models comprises quarterly macroeconomic U.S. data for the period 1952:Q1 - 2001:Q4.

The time-series used in the estimation of long-run relations (steady-state) are the private consumption, the after-tax labor income, the net wealth of households and nonprofit organizations, as well as its components, namely, the stock market wealth (we also distinguish direct property and indirect property of stocks) and the non-stock market wealth. In the estimation of dynamic equations, it was also tested the inclusion of the following variables: the inflation rate, the unemployment rate, the interest rate,

\footnotetext{
${ }^{13}$ We used the following econometric software in the estimation of models: PcGive Professional version $10.0 b$, Econometric Modelling, developed by Jurgen A. Doornik, distributed as part of GiveWin 2.02 (June 2001) by Timberlake Consultants.
} 
the confidence index, the budget surplus, the Current Accounts surplus and the rate of growth of GDP.

Data about consumption, income and wealth were calculated at 1996 prices $^{14}$, at per capita terms and expressed in the logarithmic form. Original data concerning wealth relates to the end-period values, so we introduced a lag so that the observation of wealth in $t$ relates to the value of this variable in the beginning of the period $t+1$.

A detailed description of the used information is presented in Annex II.

In sections 5.2 and 5.3, we estimate, respectively, several long-run relations and short-run dynamic equations, and analyze main results.

\subsection{Long-run relation}

The estimation of equations (1), (2) and (3) will depend on the characteristics of time-series.

First, it's necessary to analyze the existence of unit roots in time-series. Empirical evidence suggest that consumption, wealth (and its components) and income are integrated of order 1, I(1). Second, if consumption and its explanatory variables are time-series of the same integration order, it becomes necessary to analyze the existence of cointegration between the variables.

A brief graphical analysis of time-series of the variables included in the long-run specifications lead us to suspect that they constitute non-stationary processes, with a strong trend component. In Figures 3, 4 and 5 we present the time-series of the variables included in the long-run equations (specifications (1), (2) and (3)), to whom we test the existence of unitary roots and, later, of cointegration.

\footnotetext{
${ }^{14}$ We used private consumption deflator.
} 
Figure 3 - Time -series of consumption, income and aggregate wealth (variables of specification (1)).
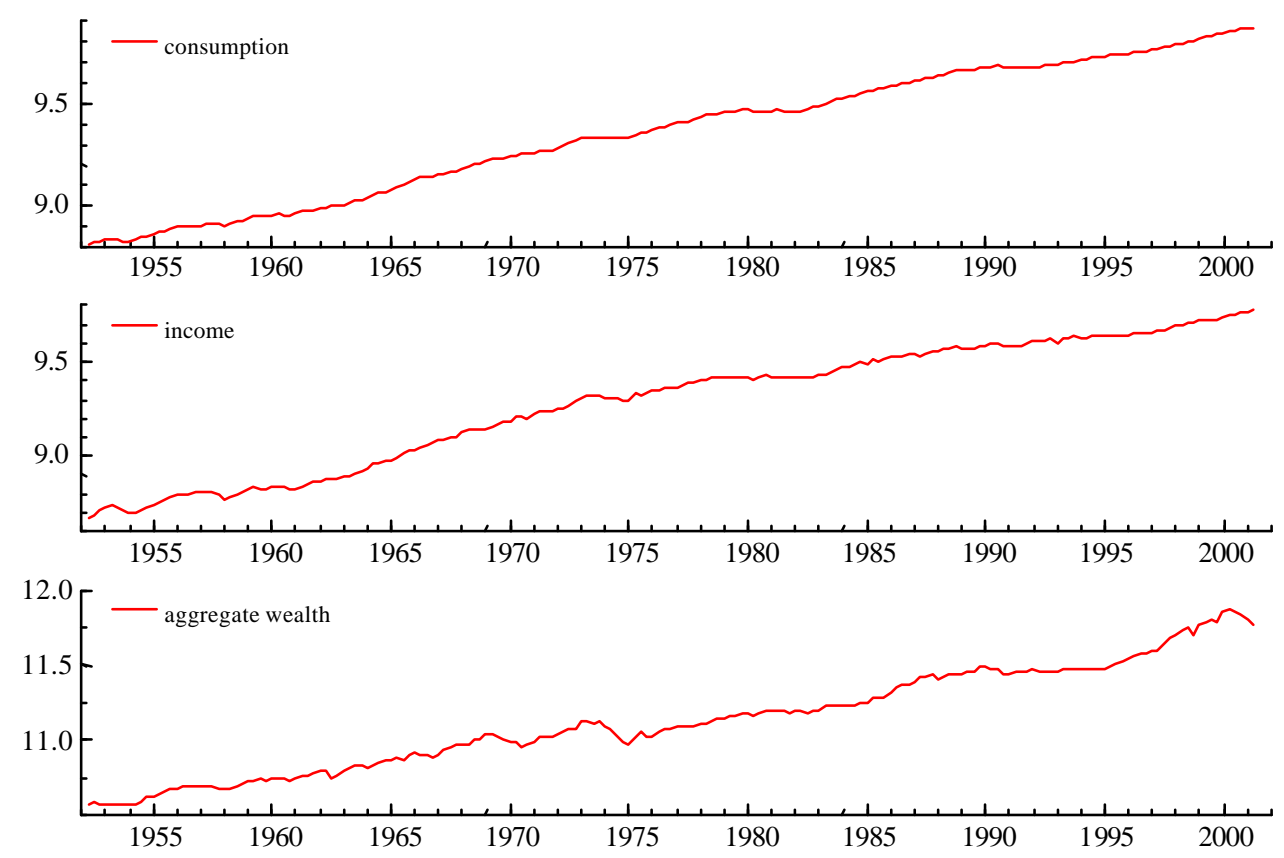

Fonte: Flow of Funds Accounts, Board of Governors of Federal Reserve System; U. S. Department of Commerce, Bureau of Economic Analysis; author's calculus.

Figure 4 - Time-series of consumption, income, stock market wealth and non-stock market wealth (variables of specification (2)).
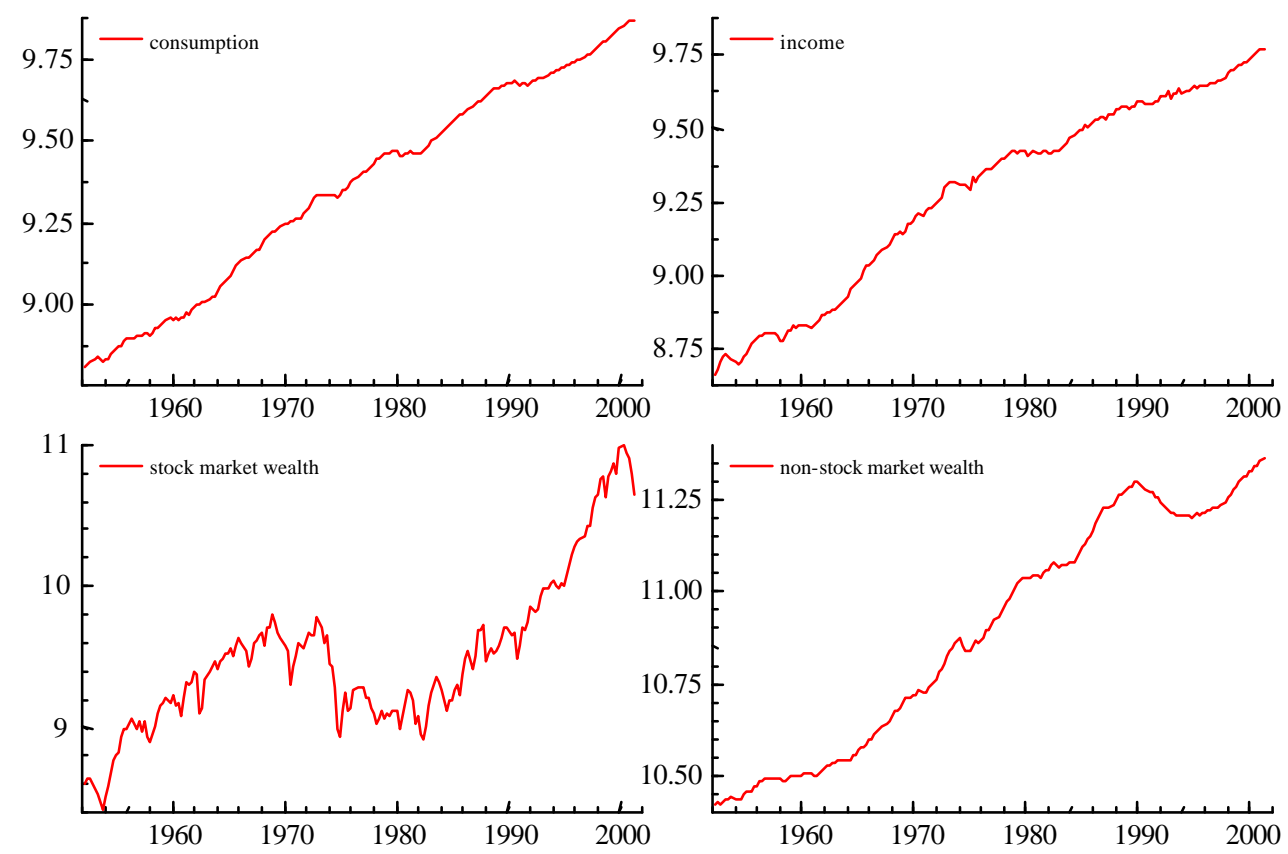

Fonte: Flow of Funds Accounts, Board of Governors of Federal Reserve System; U. S. Department of Commerce, Bureau of Economic Analysis; author's calculus. 
Figure 5 - Time-series of consumption, stock market wealth (directly held), stock market wealth (indirectly held) and non-stock market wealth (variables of specification (3)).
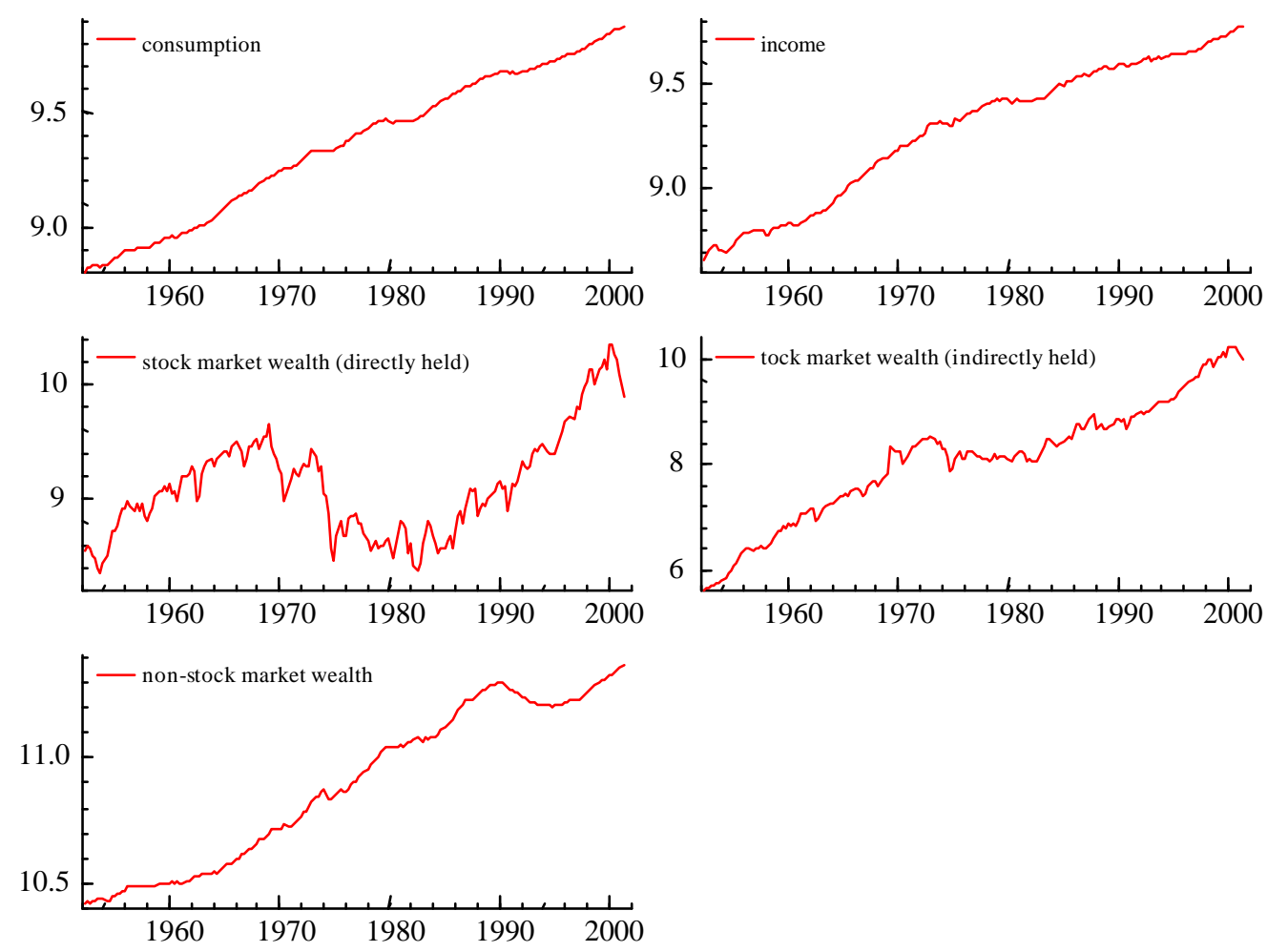

Source: Flow of Funds Accounts, Board of Governors of Federal Reserve System; U. S. Department of Commerce, Bureau of Economic Analysis; author's calculus.

To test the existence of unit roots, we applied ADF tests (Augmented DickeyFuller) to the time-series for different lags (k). Results are presented in Tables 1 and $2 .{ }^{15}$

In a first stage, we applied the tests to the variables in levels and tested the existence of a unit root, against the alternative hypothesis that the time-series are stationary. Then, we applied the tests to first-order differences and tested the hypothesis that the time-series are stationary in differences.

Results suggest that time-series have a unit root. When applied to first-order differences, the tests suggest that series are stationary in differences, a feature that emphasizes the hypothesis that variables are integrated of order 1.

\footnotetext{
${ }^{15}$ To a brief revision of alternative tests to the existence of unit roots, see, for example, Harris (1995) e Maddala and Kim (1998).
} 
Tabl e 1-ADF tests to the variables' cointegration order (variables in levels ). ${ }^{\text {a }}$

\begin{tabular}{|c|c|c|c|c|c|c|c|c|c|}
\hline & \multicolumn{7}{|c|}{ Augmented-Dickey Fuller t-Statistic } & \multicolumn{2}{|c|}{ Critical values $^{\mathrm{d}}$} \\
\hline & $\mathrm{Lag}=0^{\mathrm{b}}$ & $\mathrm{Lag}=1$ & $\operatorname{Lag}=2$ & $\mathrm{Lag}=3$ & $\operatorname{Lag}=4$ & $\operatorname{Lag}=8$ & $\operatorname{Lag}=14^{\mathrm{c}}$ & $1 \%$ Level & $5 \%$ Level \\
\hline$c_{t}$ & -0.7536 & -1.283 & -1.464 & -1.847 & -1.647 & -1.423 & -1.296 & -3.47 & -2.88 \\
\hline $\mathrm{w}_{\mathrm{t}}$ & -2.589 & -2.851 & $-2.89 *$ & $-3.246^{*}$ & $-3.353^{*}$ & $-3.024^{*}$ & -2.532 & -3.47 & -2.88 \\
\hline stw $_{\mathrm{t}}$ & -1.645 & -1.762 & -1.654 & -1.739 & -1.675 & -1.21 & -1.047 & -3.47 & -2.88 \\
\hline stwd $_{t}$ & -1.601 & -1.722 & -1.675 & -1.761 & -1.772 & -1.236 & -1.096 & -3.47 & -2.88 \\
\hline stwdit $_{t}$ & -2.382 & -2.427 & -2.361 & -2.392 & -2.37 & -2.357 & -2.131 & -3.47 & -2.88 \\
\hline $\mathrm{nstw}_{\mathrm{t}}$ & -0.8337 & -1.409 & -1.572 & -1.932 & -2.125 & -1.874 & -2.233 & -3.47 & -2.88 \\
\hline$y_{t}$ & -0.997 & -1.007 & -0.9707 & -1.039 & -0.9575 & -1.154 & -1.407 & -3.47 & -2.88 \\
\hline
\end{tabular}

Source: Author's calculus.

${ }^{\text {a }}$ Model includes trend and constant (drift).

${ }^{\mathrm{b}} \mathrm{ADF}$ test with $\mathrm{k}=0$ corresponds to DF (Dickey-Fullet) test.

${ }^{\mathrm{c}}$ The choice of $\mathrm{k}=14$ correspond $\mathrm{s}$ to the number of lags suggested by the rule of Schwert (1989):

$$
k=\operatorname{Int}\left\{c(T / 100)^{1 / d}\right\}
$$

with $k$ corresponding to the number of lags, $T$, the number of observations of the sample, $\mathrm{c}=12 \mathrm{e} d=4$.

${ }^{\mathrm{d}}$ Critical values suggested by MacKinnon (1991). 
Table 2 - ADF tests to the variables' cointegration order (variables in first-order differences). ${ }^{\text {a }}$

Augmented-Dickey Fuller t-Statistic

\begin{tabular}{|c|c|c|c|c|c|c|c|c|c|}
\hline & \multicolumn{7}{|c|}{ Augmented-Dickey Fuller t-Statıstıc } & \multicolumn{2}{|c|}{ Critical values “ } \\
\hline & $\mathrm{Lag}=0^{\mathrm{b}}$ & $\mathrm{Lag}=1$ & $\mathrm{Lag}=2$ & $\mathrm{Lag}=3$ & $\mathrm{Lag}=4$ & $\mathrm{Lag}=8$ & $\operatorname{Lag}=14^{\mathrm{c}}$ & $1 \%$ Level & $5 \%$ Level \\
\hline$\Delta c_{t}$ & $-9.818 * *$ & $-7.19 * *$ & $-5.211 * *$ & $-5.367 * *$ & $-6.025 * *$ & $-4.431 * *$ & $-3.255^{*}$ & -3.47 & -2.88 \\
\hline$\Delta \mathrm{w}_{\mathrm{t}}$ & $-12.62 * *$ & $-9.217 * *$ & $-6.777 * *$ & $-5.838 * *$ & $-5.458 * *$ & $-4.502 * *$ & $-4.275^{* *}$ & -3.47 & -2.88 \\
\hline$\Delta \mathrm{stw}_{\mathrm{t}}$ & $-12.91 * *$ & $-10.01 * *$ & $-7.817 * *$ & $-6.963 * *$ & $-6.278 * *$ & $-4.597 * *$ & $-3.69 * *$ & -3.47 & -2.88 \\
\hline$\Delta$ stwd $_{t}$ & $-12.78 * *$ & $-9.647 * *$ & $-7.61 * *$ & $-6.559 * *$ & $-6.185^{* *}$ & $-4.544 * *$ & $-3.666^{* *}$ & -3.47 & -2.88 \\
\hline$\Delta$ stwdi $_{\mathrm{t}}$ & $-13.54 * *$ & $-10.51 * *$ & $-7.976^{* *}$ & $-7.4 * *$ & $-6.787 * *$ & $-4.246 * *$ & $-3.204 *$ & -3.47 & -2.88 \\
\hline$\Delta \mathrm{nstw}_{\mathrm{t}}$ & $-8.363 * *$ & $-6.014 * *$ & $-4.596 * *$ & $-3.963 * *$ & $-3.719 * *$ & $-3.713 * *$ & -2.829 & -3.47 & -2.88 \\
\hline$\Delta \mathrm{y}_{\mathrm{t}}$ & $-12.86^{* *}$ & $-8.93 * *$ & $-7.071 * *$ & $-6.597 * *$ & $-6.821 * *$ & $-4.386^{* *}$ & -2.647 & -3.47 & -2.88 \\
\hline
\end{tabular}

Source: Author's calculus.

${ }^{a}$ Model includes trend and constant (drift).

${ }^{\mathrm{b}} \mathrm{ADF}$ test with $\mathrm{k}=0$ corresponds to DF (Dickey-Fullet) test.

${ }^{\mathrm{c}}$ The choice of $\mathrm{k}=14$ corresponds to the number of lags suggested by the rule of Schwert (1989):

$$
k=\operatorname{Int}\left\{c(T / 100)^{1 / d}\right\},
$$

with $k$ corresponding to the number of lags, $T$, the number of observations of the sample, $\mathrm{c}=12 \mathrm{e} \mathrm{d}=4$.

${ }^{\mathrm{d}}$ Critical values suggested by MacKinnon (1991). 
In order to estimate long-run relations, we use Stock and Watson (1993) procedure, and we include lags and leads or order $4 .{ }^{17}$ In a first stage, when we detect heterokedasticity and serial autocorrelation in the estimation by DOLS, we used standard deviations proposed by Newey e West (1987) with a lag truncation parameter of 4. On the basis of this estimation and using Engle e Granger (1987) methodology, we apply ADF tests to the error-terms of the cointegration vector, as a form of detecting the existence of cointegration. ${ }^{18}$ Finally, in cases where we detect the existence of cointegration, long-run relation was re-estimated using DGLS method. All relations were estimated with variables in logarithms and levels, in order to obtain, respectively, estimates of elasticities and marginal propensities to consume. $^{19}$

Tables 3, 4 and 5 provide a brief summary of major results of estimation via DOLS and via DGLS of equations (1), (2) and (3). To each model, we present the DOLS and DGLS estimates of cointegration vector (constant is omitted). We also present the results of $\mathrm{ADF}$ tests to each cointegration vector.

The results of the estimation of equation(1) via DOLS, shown in Table 3, lead us to conclude that the long-run elasticity of consumption in order to aggregate net wealth is 0.28 , whereas the elasticity of consumption in order to income is 0.67 , a value that, although inferior to 1 , is similar to those found in previous empirical studies. By the other hand, when the relation is estimated with variables in levels, we obtain an estimate of the marginal propensity to consume wealth of approximately 0.038, which confirms the results obtained in previous works that show that the impact of 1 additional dollar of net wealth is comprised to the interval of 3 to 5 cents of additional consumption. Additionally, the ADF tests applied to the error-terms of cointegration vector show that the same are stationary, which constitutes an evidence of time-series cointegration. ${ }^{20}$ When we, explicitly, model serial autocorrelation ${ }^{21}$, the cointegration vector parameters don't change significantly ( 0.17 e 0.81 , respectively), although, in the case of the elasticity of consumption to income, the estimate

\footnotetext{
${ }^{17}$ Results aren't sensible to the choice of different values for $k$.

${ }^{18}$ To a brief review of alternative cointegration tests, see, for example, Harris (1995) and Maddala and Kim (1998).

${ }^{19}$ Some authors estimate consumption functions as ratios of income. See, for example, Boone et al. (1998), Maki and Palumbo (2001) and Mehra (2001), among others.

${ }^{20}$ Tests reject null hypothesis of the error-terms being integrated of order 1 , to a significance level of 1 and $5 \%$.

${ }^{21}$ It was adopted the presumption that error-terms follow an autoregressive process of order 1, which was sufficient to correct serial autocorrelation.
} 
approximates further to 1 . We should note that the coefficients associated to the wealth variable - when the relation is estimated in levels - can be interpreted as identifying the quarterly real after-tax rate of return of detained assets. ${ }^{22}$ Thus, the results allow us to conclude that annual real after-tax profitability rate of return of aggregate wealth is approximately 8.3\% (estimate through DGLS) and 19.5\% (estimate through DOLS). ${ }^{23}$

Table 3 - Coefficients of cointegration equation (1).

\begin{tabular}{|c|c|c|c|c|}
\hline \multirow[t]{3}{*}{ Model: } & \multicolumn{4}{|c|}{$c_{t}=\beta w_{t}+\delta Y_{t}+\sum_{i=-4}^{4} \beta_{i} \Delta w_{, t+i}+\sum_{i=-4}^{4} \delta_{i} \Delta y_{, t+i}+u_{1 t}$} \\
\hline & \multicolumn{2}{|c|}{$\beta$} & \multicolumn{2}{|c|}{$\delta$} \\
\hline & Log & Level & Log & Level \\
\hline DOLS & $\begin{array}{c}0.281627 \\
(0.014901)\end{array}$ & $\begin{array}{c}0.0378959 \\
(0.0060422)\end{array}$ & $\begin{array}{c}0.670674 \\
(0.017963)\end{array}$ & $\begin{array}{c}0.833472 \\
(0.037732)\end{array}$ \\
\hline ADF t-test & \multicolumn{2}{|c|}{$-2.591 * *(\log )$} & \multicolumn{2}{|c|}{$-2.127 *($ Level $)$} \\
\hline DGLS & $\begin{array}{l}0.167804 \\
(0.04452)\end{array}$ & $\begin{array}{l}0.0191899 \\
(0.005136)\end{array}$ & $\begin{array}{l}0.806516 \\
(0.05317)\end{array}$ & $\begin{array}{l}0.949023 \\
(0.03717)\end{array}$ \\
\hline
\end{tabular}

Source: Author's calculus.

Notes: Symbols * and ** denote rejection of significance to a significance level of 1 and $5 \%$, respectively. When applying ADF tests, we consider models without trend, without drift and with four lags. We also used critical values from MacKinnon (1991).

When we disaggregate wealth in stock-market wealth and non-stock market wealth, we can see (Table 4) that the long-run elasticity of consumption to stock market wealth is, approximately, 0.057 (or a marginal propensity to consume approximately 0.037). The ADF tests applied to the error-terms of estimation also confirm that they are stationary and, therefore, there is evidence of cointegration in the time-series. By the other hand, the estimation of the equation via DGLS, doesn't

\footnotetext{
22 This interpretation is possible when we assume the presupposition that consumption equals permanent income.

${ }^{23}$ Under permanent income hypothesis, consumption is given by:

$$
c_{t}=\delta\left(r w_{t}+y_{t}+\sum_{i=1}^{\infty}(1+r)^{-i} E_{t} \Delta w_{, t+i}\right) \text {. }
$$

If economic agents and market discount future at the same rate, then $\delta$ equals 1 , that is, consumption will equal permanent income expression under brackets). The estimate that is obtained for the cointegration equation coefficient associated to income (in levels) is an estimate of $\delta$ (present value of expected changes in labor income is stationary). In Table 3, the estimate of $\delta$ is 0.833472 (DOLS) and of 0.949023 (DGLS), which implies, respectively, an annual real after-tax rate of return approximately $19.5 \%$ and $8.3 \%$ (which we obtain, dividing the coefficient associated to net wealth, $\beta$, by the coefficient associated to income, $\delta$ ).
} 
bring significant changes, with the exception of the coefficient associated to stockmarket wealth that is not statistically significant at a significance bvel of $1 \%$. The estimation via DGLS and DOLS suggests an annual, real and after-tax rate of return of stock-market wealth of, respectively, $7.6 \%$ and $24.3 \%$.

Finally, the estimation of the equation (3) via DOLS reveals that stock-market wealth that is directly held has an impact of about 3.5 times superior to that associated to stock-market wealth that is indirectly held, a feature that is not surprising, not only because direct property implies a permanent search of information from agents in order to match the evolution of portfolios (and to predict future evolution), but also and, consequently - because of the larger perception of changes in wealth originated by that evolution. The ADF tests applied to the error-terms reveal the presence of cointegration. By the other hand, the estimation through DGLS reveals that the disaggregating of stock-market wealth is not statistically significant. Results also suggest: an annual real after-tax rate of return of assets directly held in the form of stocks of $6.7 \%$ (DGLS) and $41.3 \%$ (DOLS); an annual real after-tax rate of return of assets indirectly held in the form of stocks of $8.1 \%$ (DGLS) and $11.1 \%$ (DOLS). Finally, when equation (3) is estimated by DGLS, each of the components of stockmarket wealth is not statistically significant at a significance level of $10 \%$. 
Table 4 - Coefficients of cointegration equation (2).

\begin{tabular}{|c|c|c|c|c|c|c|}
\hline \multirow[t]{3}{*}{ Model: } & \multicolumn{6}{|c|}{$c_{t}=\alpha s t w_{t}+\theta n s t w_{t}+d y_{t}+\sum_{i=-4} \alpha_{i} ? s t w_{, t+i}+\sum_{i=-4} \theta_{i} ? n s t w_{, t+i}+\sum_{i=-4} d_{i} ? y_{, t+i}+u_{2 t}$} \\
\hline & \multicolumn{2}{|c|}{$\alpha$} & \multicolumn{2}{|c|}{$\theta$} & \multicolumn{2}{|c|}{$\delta$} \\
\hline & $\log$ & Level & $\log$ & Level & $\log$ & Level \\
\hline DOLS & $\begin{array}{c}0.0574961 \\
(0.0035633)\end{array}$ & $\begin{array}{c}0.0369195 \\
(0.0044678)\end{array}$ & $\begin{array}{c}0.286877 \\
(0.018371)\end{array}$ & $\begin{array}{c}0.0727063 \\
(0.0071614)\end{array}$ & $\begin{array}{l}0.612802 \\
(0.021377)\end{array}$ & $\begin{array}{c}0.660954 \\
(0.037735)\end{array}$ \\
\hline ADF t-test & & $-2.819 * *(\log )$ & & & $-2.631 * *$ (Level) & \\
\hline DGLS & $\begin{array}{c}0.0321709 * \\
(0.01303) \\
\end{array}$ & $\begin{array}{r}0.0159935^{*} \\
(0.006261)\end{array}$ & $\begin{array}{r}0.229116 \\
(0.05884) \\
\end{array}$ & $\begin{array}{c}0.0365928 \\
(0.01169) \\
\end{array}$ & $\begin{array}{c}0.706595 \\
(0.07087) \\
\end{array}$ & $\begin{array}{r}0.870402 \\
(0.05878) \\
\end{array}$ \\
\hline
\end{tabular}

Source: Author's calculus.

Notes: Symbols * and ** denote rejection of significance to a significance level of 1 and $5 \%$, respectively. When applying ADF tests, we consider models without trend, without drift and with four lags. We also used critical values from MacKinnon (1991). 
Table 5 - Coefficients of cointegration equation (3).

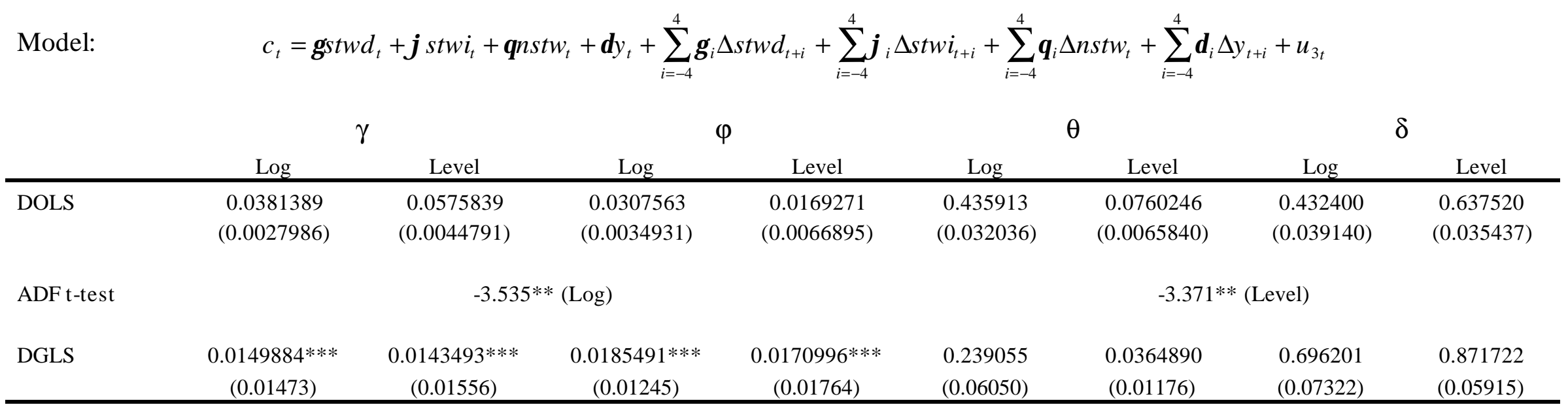

Source: Author's calculus.

Notes: Symbols * and ** denote rejection of significance to a significance level of 1 and $5 \%$, respectively. When applying ADF tests, we consider models without trend, without drift and with four lags. We also used critical values from MacKinnon (1991). 
From the graphical analysis of the estimated long-run relations (Figure 6), we can emphasize that the private consumption have been inferior to its long-run level of equilibrium along the seventies, which is not surprising because of the oil shocks and the rupture of the international system of payments. We can also see that, along the nineties, the private consumption have been superior to its long-run level of equilibrium, a behavior sustained, probably, by the strong appreciations of stock markets, which seems to confirm the idea that this period was characterized by abnormally high rates of return of stock markets.

Figure 6 - Cointegration relation - specification (1).
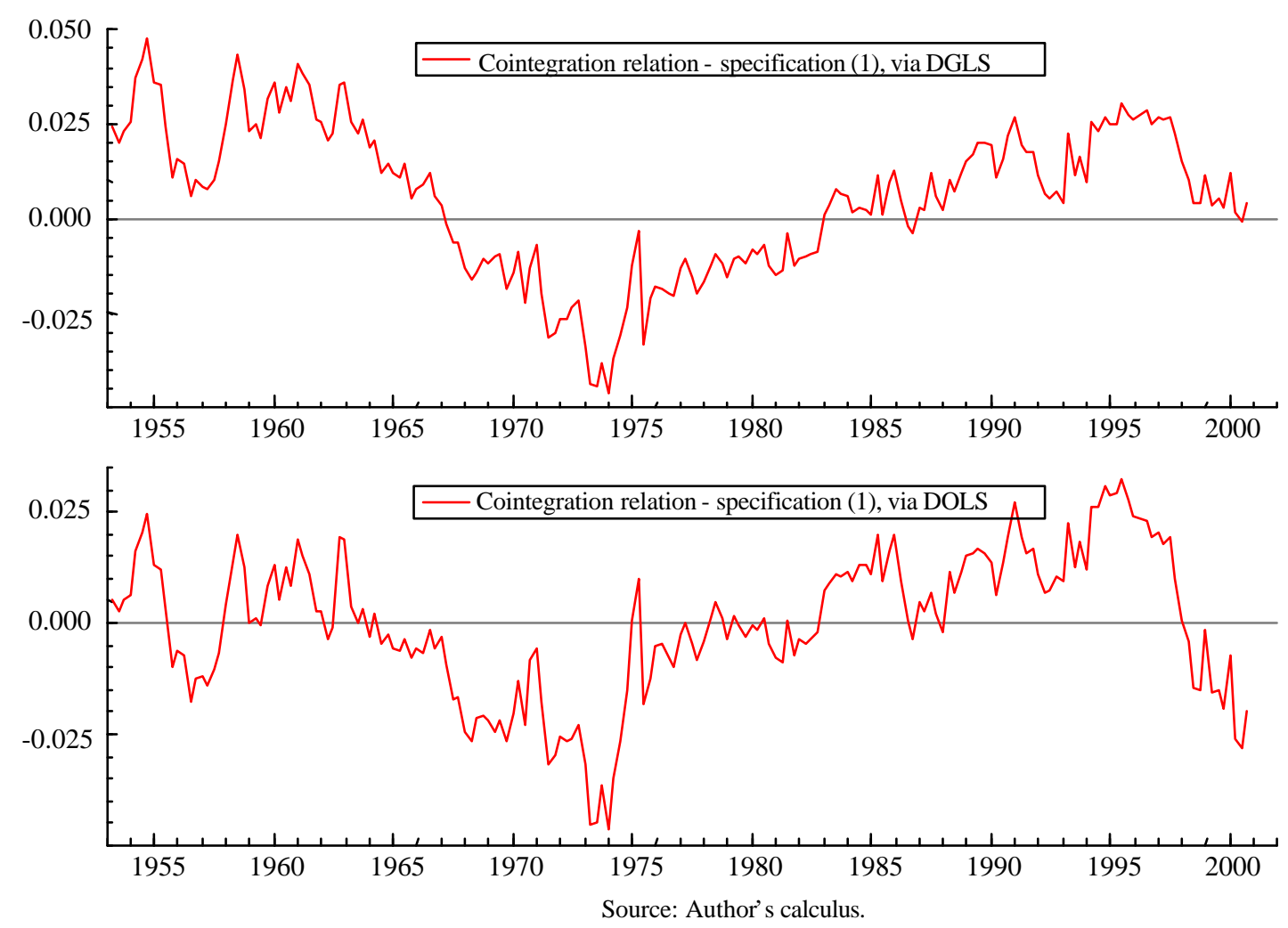
Figure 7 - Cointegration relation - specification (2).
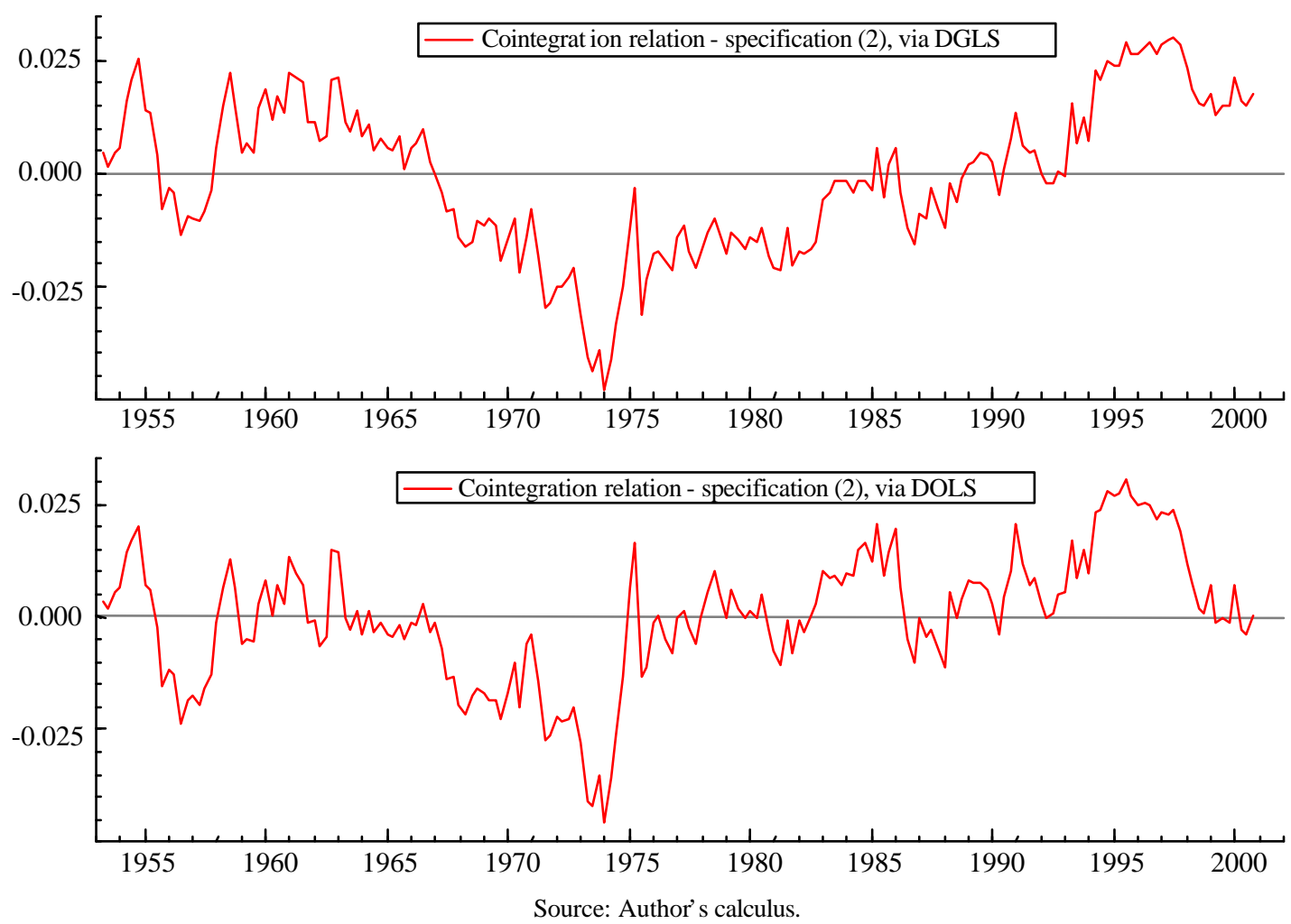

Figura 8 - Cointegration relation - specification (3).
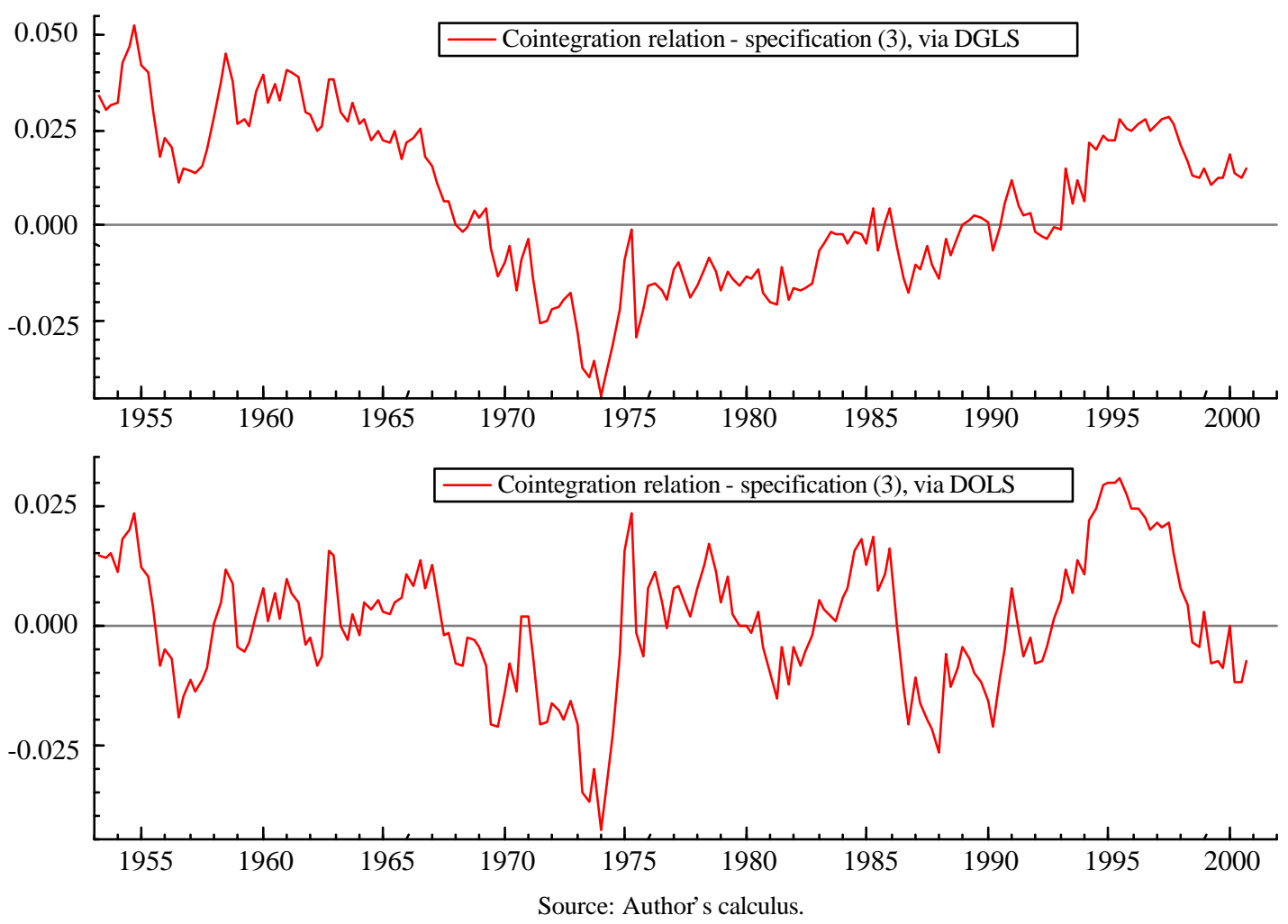


\subsection{Short-run dynamics}

Short-run dynamics is represented by equations (1'), (2') and (3'). We presuppose the existence of a long-run relation between consumption, income and wealth (and its components ) - cointegration relation -, but, in the short-run, temporary divergences may occur.

Dynamic equations were estimated, including not just the lagged values of the variables included on long-run relations (equations (1), (2) and (3)), but also (exogenous) variables that, although literature doesn't attribute any role in the determination of the long-run relation, can bring additional information concerning the short-run dynamics. As exogenous variables, we include: the unemployment rate (unrate), the inflation rate (inflation), the interest rate of the 3-months Treasury bills $(t b 3 m s)$ - which is used as a proxy for the short-run interest rate -, the rate of interest of mortgages (mortgage) - which is used as a proxy for the long-run interest rate -, the consumer's sentiment index (sentiment), the budget surplus (budget), the Balance of Current Accounts (bopbca) and the rate of growth of GDP (rategdp).

Long-run component was included in the dynamic equations, considering the cointegration coefficients of the estimations through DOLS and DGLS.

Before proceeding to the estimation of the equations, it is necessary to apply the ADF tests to each one of the (exogenous) variables, in order to include only stationary ones.

The ADF tests reveal that all (exogenous) variables, with the exception of the rate of growth of GDP, are integrated of order 1, being stationary in first-order differences, as we can observe in Table 6. Consequently, we include in the estimation of the dynamic equations, all (exogenous) variables in first-order differences, with the exception of the rate of growth of GDP, which is included in levels. 
Table 6 - ADF tests to the order of integration of exogenous variables.

\begin{tabular}{|c|c|c|c|}
\hline & \multicolumn{3}{|c|}{ Critical values } \\
\hline & $\begin{array}{l}\text { Dickey-Fuller } \\
\text { t-Statistic }\end{array}$ & $\begin{array}{l}1 \text { Percent } \\
\text { Level }\end{array}$ & $\begin{array}{l}5 \text { Percent } \\
\text { Level }\end{array}$ \\
\hline \multicolumn{4}{|l|}{ unrate } \\
\hline Level & -1.892 & -3.488 & -2.887 \\
\hline 1st difference & $-4.367 * *$ & -3.489 & -2.887 \\
\hline \multicolumn{4}{|l|}{ inflation } \\
\hline level & -2.138 & -3.488 & -2.887 \\
\hline 1st difference & $-5.298 * *$ & -3.489 & -2.887 \\
\hline \multicolumn{4}{|l|}{$\mathrm{tb} 3 \mathrm{~ms}$} \\
\hline level & -2.161 & -3.488 & -2.887 \\
\hline 1st difference & $-3.742 * *$ & -3.489 & -2.887 \\
\hline \multicolumn{4}{|l|}{ mortgage } \\
\hline level & -1.799 & -3.488 & -2.887 \\
\hline 1st difference & $-4.586 * *$ & -3.489 & -2.887 \\
\hline \multicolumn{4}{|l|}{ Sentiment } \\
\hline Level & -2.15 & -3.488 & -2.887 \\
\hline 1st difference & $-4.593 * *$ & -3.489 & -2.887 \\
\hline \multicolumn{4}{|l|}{ budget } \\
\hline Level & -0.6375 & -3.488 & -2.887 \\
\hline 1st difference & $-3.919 * *$ & -3.489 & -2.887 \\
\hline \multicolumn{4}{|l|}{ bopbca } \\
\hline Level & -0.4399 & -3.488 & -2.887 \\
\hline 1st difference & $-4.084 * *$ & -3.489 & -2.887 \\
\hline \multicolumn{4}{|l|}{ rategdp } \\
\hline Level & $-4.689 * *$ & -3.488 & -2.887 \\
\hline 1st difference & $-6.714^{* *}$ & -3.489 & -2.887 \\
\hline
\end{tabular}

Source: Author's calculus.

Notes: Model includes a constant and four lags; we use critical values proposed by MacKinnon (1991).

The results of the estimation of the equation (1') are summarized in Table 7, where we only include the variables that are statistically significant.

Results suggest that lagged values of wealth' and income' growth are not statistically significant. This observation is consistent with the forward-looking consumers' behavior, because it suggests that some consumers have information about their future wealth and income that it's not captured by the lags of these variables, and that consumers answer to that information, by changing present consumption. This 
result, equally, suggests that realized capital gains have a larger impact on consumption than potential capital gains. ${ }^{24}$

On the other hand, it can be shown that lagged values of the growth of consumption are statistically significant, which can be interpreted as a sign of some delay in the adjustment of consumption and represents a statistical rejection of permanent income hypothesis, since, according to this hypothesis, it's not possible to predict future consumption. In fact, the model shows that the increase of the consumption's growth rate in the previous period in 1 percentile point implies the acceleration of the consumption's rate of growth in the following period of the order of 0.21 percentile points.

Another feature that deserves reference has to do with the fact that consumption contemporaneously answers to changes in income and wealth, which can be an indicator of the existence of liquidity constraints or that consumers follow rules of decision: the increase of the current rate of growth of wealth in 1 percentile point leads to the acceleration of the rate of growth of consumption of between 0.035 and 0.038 percentile points; the increase of the current rate of growth of income in 1 percentile point implies the acceleration of the rate of growth of consumption of, approximately, 0.23 percentile points.

It was also verified that the inflation rate, the short-run rate of interest, the longrun rate of interest, the consumer sentiment index, the budget surplus and the Balance of Current Accounts are statistically significant and, therefore, they bring additional information to the analysis of the behavior of the short-run dynamics of consumption. Among the group of variables initially proposed, we exclude the unemployment rate and the rate of growth of GDP ${ }^{25}$, which indicates that, for the adopted theoretical model and the chosen sample period, the first doesn't seem to constitute a good proxy for consumers' uncertainty and the second, to analyze the existence of habit formation in the consumption patterns.

In what concerns to inflation, we observe that the increase of inflation rate in 1 percentile point contributes to diminish the rate of growth of consumption in about 0.002 percentile points.

\footnotetext{
${ }^{24}$ In fact, since the lagged values of growth of wealth aren't statistically significant, results suggest that consumers are liquidity-constrained or that capital gains are, partially, considered as temporary, so that the impact of realized capital gains is greater than that associated to potential capital gains.

${ }^{25}$ Results suggest that these variables are not statistically significant.
} 
In what concerns to interest rates (short-run and long-run), the results point out opposite directions: the short-run interest rate has a positive impact on the rate of growth of consumption of approximately 0.0016 percentile points for each percentile point of increase, while the long-run interest rate has a negative impact of approximately 0.003 percentile points. These results aren't completely surprising since we used, as a proxy for the short-run interest rate, the 3-month interest rate of Treasury bills and, as a proxy for the long-run interest rate, the mortgages interest rate. In fact, the first can be understood, mainly, as a rate of return of an asset detained by consumers, while the second represents a cost, since positive changes in this variable imposes restrictions on consumer expenditures. Therefore, results suggest that, in the short-run, income effects are greater than substitution effects and, in the long-run, the opposite occurs.

In what concerns to consumer sentiment index, the results confirm the hypothesis that consumption decisions depend not only on the capacity to buy, but also on the level of consumers' optimism and/or pessimism.

In what concerns to budget surplus and the Balance of Current Accounts, the results suggest a small impact on the rate of growth of consumption, although statistically significant.

Finally, the coefficient associated to long-run component has a negative sign, confirming the idea that deviations in order to that component are corrected in the following periods. Its value (approximately -0.04 in the estimate that uses the vector of cointegration estimated by DOLS and -0.044 in the case of the estimation via DGLS) suggests that the correction is extremely slow, which constitutes an indicator that consumers, gradually, adjust their expenditures after the realization of gains and/or losses in income and wealth. Therefore, only after the verification of a sufficiently long period of losses and/or gains - that agents perceive as permanent - will the consumption patterns change, which can be, simultaneously, interpreted as an evidence of the presence habit formation This result also constitutes an evidence of the "indirect" channel of wealth effect, since the connection between changes in wealth and the adjustment of consumption patterns is not immediate. 
Table 7 - Dynamic equations, specification (1').

\begin{tabular}{|c|c|c|}
\hline & \multicolumn{2}{|c|}{$e c t_{t-1}=c_{t-1}-\hat{\beta} w_{t-1}-\hat{\delta} y_{t-1}$} \\
\hline & DOLS & DGLS \\
\hline Constant & $\begin{array}{c}0.00258573 \\
(0.00042713)\end{array}$ & $\begin{array}{c}0.00252398 \\
(0.00043684)\end{array}$ \\
\hline$e^{e c t} t_{t-1}$ & $\begin{array}{c}-0.0399231 * \\
(0.018642)\end{array}$ & $\begin{array}{r}-0.0444326 \\
(0.016231)\end{array}$ \\
\hline$\Delta c_{t-1}$ & $\begin{array}{c}0.212467 \\
(0.063089)\end{array}$ & $\begin{array}{c}0.206807 \\
(0.064275)\end{array}$ \\
\hline$\Delta \mathrm{w}_{\mathrm{t}}$ & $\begin{array}{c}0.0354013 * \\
(0.013703)\end{array}$ & $\begin{array}{c}0.0376341 * \\
(0.014060)\end{array}$ \\
\hline$\Delta \mathrm{y}_{\mathrm{t}}$ & $\begin{array}{c}0.231092 \\
(0.029124)\end{array}$ & $\begin{array}{c}0.234834 \\
(0.029172)\end{array}$ \\
\hline$\Delta$ inflation $_{t}$ & $\begin{array}{c}-0.00192830 * * \\
(0.0010540)\end{array}$ & $\begin{array}{c}-0.00190693 * * \\
(0.0010404)\end{array}$ \\
\hline$\Delta \mathrm{tb} \mathrm{ms}_{\mathrm{t}}$ & $\begin{array}{c}0.000932491 * \\
(0.00036499)\end{array}$ & $\begin{array}{c}0.000934491 * \\
(0.00035097)\end{array}$ \\
\hline$\Delta \mathrm{tb} 3 \mathrm{~ms}_{\mathrm{t}-2}$ & $\begin{array}{c}0.000660479 * * \\
(0.00030624)\end{array}$ & $\begin{array}{c}0.000658584 * * \\
(0.00030605)\end{array}$ \\
\hline$\Delta$ mortgage $_{\mathrm{t}}$ & $\begin{array}{l}-0.00173257 \\
(0.00050260)\end{array}$ & $\begin{array}{l}-0.00175604 \\
(0.00050676)\end{array}$ \\
\hline$\Delta$ mortgage $_{\mathrm{t}-1}$ & $\begin{array}{l}-0.00144106 \\
(0.00036524)\end{array}$ & $\begin{array}{l}-0.00146905 \\
(0.00035456)\end{array}$ \\
\hline$\Delta$ sentiment $_{\mathrm{t}}$ & $\begin{array}{c}0.000158158 \\
(4.79 \mathrm{E}-05)\end{array}$ & $\begin{array}{c}0.000154992 \\
(4.81 \mathrm{E}-05)\end{array}$ \\
\hline$\Delta$ sentiment $_{\mathrm{t}-1}$ & $\begin{array}{c}0.000126446^{*} \\
(6.82 \mathrm{E}-05)\end{array}$ & $\begin{array}{l}0.000127810^{*} \\
(6.59 \mathrm{E}-05)\end{array}$ \\
\hline$\Delta$ sentiment $_{\mathrm{t}-2}$ & $\begin{array}{c}0.000101793 * * \\
(3.80 \mathrm{E}-05)\end{array}$ & $\begin{array}{c}0.000106193 * * \\
(3.60 \mathrm{E}-05)\end{array}$ \\
\hline$\Delta$ budget $_{\mathrm{t}}$ & $\begin{array}{c}0.00000696335^{*} \\
(2.52 \mathrm{E}-06)\end{array}$ & $\begin{array}{c}0.00000760932 * \\
(2.44 \mathrm{E}-06)\end{array}$ \\
\hline$\Delta$ budget $_{\mathrm{t}-2}$ & $\begin{array}{c}0.00000794183 * \\
(2.52 \mathrm{E}-06)\end{array}$ & $\begin{array}{c}0,00000889583 \\
(2.30 \mathrm{E}-06)\end{array}$ \\
\hline$\Delta$ bopbca $_{t-2}$ & $\begin{array}{c}-0.0000248701 * \\
(9.61 \mathrm{E}-06)\end{array}$ & $\begin{array}{c}-0.0000276168 * \\
(9.61 \mathrm{E}-06)\end{array}$ \\
\hline
\end{tabular}

Source: Author's calculus.

Notes: Symbols $* * *$ and $* * *$ denote significance rejection at a level of $1,5 \%$ and $10 \%$, respectively.

The estimation of specifications (2') and (3') revealed that exogenous variables, the disaggregating of wealth and the long-run component were not statistically significant, which is the reason for which we only provide a summary of the results of the estimation of equation (1'). 


\section{Conclusions}

The fluctuations of financial markets along the nineties have revived the debate on the role of these markets, in particular, of stock markets, on the determination of real economic activity.

In this work, we should emphasize some results and, although, in this area, theoretical analysis is still not gathering consensus and empirical evidence is still inconclusive, the pertinence of the same is relevant, not only because of the questions they address, but also because they allow us to foresee future directions of research.

In the estimation of wealth effects, we considered several long-run (steady-state) relations between consumption and wealth, and then we moved to the analysis of the short-run dynamics.

The results of the estimation of the long-run relations suggest that, in the U.S.A., for the period 1953:Q1 - 2001:Q4, each additional dollar of stock-market wealth induces an increase of 3.7 cents on private consumption, in line with the results obtained in previous works.

Although literature refers that the impact (on consumption) of different categories of assets can be different, it hadn't yet been addressed the question of knowing if wealth effects associated to direct property of stocks are of the same magnitude of those generated by indirect property. A priori, we expected that direct property' wealth effects could be more robust, because the direct property requires from the stockholder a permanent search for information in order to accompany the evolution of stock prices and, consequently, it allows a larger perception of the wealth changes. This work suggests that, in fact, the impact is substantially larger, since it shows that each additional dollar of directly held stock-market wealth induces the increase of consumption of, approximately, 5.8 cents, while each additional dollar of indirectly held stock-market wealth induces the increase of consumption of only 1.7 cents, that is, the direct property' stock-market wealth effect is about 3.5 times superior to the indirect property' stock-market wealth effect.

Short-period dynamics is analyzed through the estimation of a single individual. The results suggest that consumers: have a forward-looking behavior; are influenced by the level of confidence; attribute a greater importance to realized capital gains than to potential capital gains; and follow rules of decision. 
The empirical evidence also suggests the rejection of permanent income hypothesis, which denotes its limitations and the idea, defended by Attanasio (1998) that life cycle model and permanent income hypothesis can only be tested and estimated if we use a flexible specification of individual's preferences.

Another aspect that deserves emphasis is the fact that results reveal that the correction of deviations in order to long-run relation is very slow, which means that consumers gradually adjust their expenditure patterns. This result can be explained by the existence of habit formation. Another possible explanation could be that consumers change their expenditure patterns after the verification of a sufficiently long period of abnormally high wealth losses/gains, this is, creating the expectation of new losses/gains. This result also suggests the presence of the "indirect" channel of wealth effect, since the connection between changes in wealth and changes in consumption is not immediate.

This work is just a first approach to the subject. Therefore, there are several limitations: some are theoretical; others, methodological.

One of the limitations is that the proposed model considers the (wealth) effects of stock market on real economic activity (namely, on private consumption), but it ignores the possibility that economic activity can also influence stock market and, therefore, that this market is a mere leading indicator. For example, Ludvigson and Steindel (1999) present a model in which short-run dynamics is described by a system of equations, which allows the possibility of the reflexivity in the relation between consumption and stock market. By the other hand, Tokua (2002) points out that, from the theoretical point of view, there is little space for the verification of "pure" wealth effects, since not only consumption, but also stock prices are forward-looking variables.

In addition, this work analyzes the impact of stock market on private consumption, but it ignores the impact on private investment.

The proposed approach is of partial equilibrium and not of general equilibrium. In fact, following Ludvigson and Steindel (1999) and Mehra (2001), this work considers the interest rate and wealth as exogenous variables, when a general equilibrium' analysis would require them to be endogenous. Lantz and Sartre (2001) analyze this question, showing that consumption doesn't directly react to wealth changes, but both consumption and wealth react to changes in productivity. Since the effect of these changes on those variables is not linear, there is the possibility that consumption and wealth move in opposite directions. 
Another limitation is that we have considered that the relation between consumption and wealth is stable over time, which, if is not the case, would imply that marginal propensity to consume wealth is not constant. Ludvigson and Steindel (1999), Mehra (2001) and Shirvani and Wilbratte (2002) try to highlight this aspect, emphasizing that the coefficient associated to stock-market wealth in the consumption function increased substantially during the nineties, a feature that deserves further reflection in future works.

By the other hand, from a methodological point of view, in this work, we used the ADF tests and the methodology of Engle and Granger (1987) to detect, respectively, the existence of unit roots and cointegration. However, we should note that these methodologies have limitations: the ADF tests are not powerful when compared with alternative tests, and suffer from sample dimension biases, aspects that, as Harris (1995, p. 47) refers can lead to the tendency to excessively reject the null hypothesis, when it is true, and not to reject it, when it is false; by its turn, the methodology proposed by Engle and Granger is criticized because of its weak power, its potential biases of the estimates of long-run relations in finite samples and the impossibility of applying statistical inference to the long-run parameters from t-statistics (Harris, 1995, p. 57). These limitations have led to the development of alternative tests that allow more robust results. Harris (1995) and Maddala and Kim (1998) present a detailed description of the panoply of alternative tests.

This work makes possible the questioning of some issues that constitute starting points for future works.

A potentiality to explore has to do with the possibility that fluctuations of financial might have asymmetric effects on real economic activity and, therefore, on consumption. A recent work, developed by Shirvani and Wilbratte (2000) reveals that the effects of the increases in stock prices are greater than those associated to stock prices decreases. This aspect is important, because it implies that positive wealth effects have different magnitudes from negative wealth effects, and, therefore, they might have different implications for the fluctuations of real economic activity.

Another potentiality is to analyze the role of financial deregulation/liberalization Bayoumi (1993) and Caporale and Williams (1997), among others, point out the importance of these processes for the credit expansion and the elimination of liquidity restrictions that they provide; Bonser-Neal and Dewenter (1999) emphasize the effects of level of development of financial markets on the savings rate; 
and Bekaert et al. (2001) emphasize their importance for economic growth. Therefore, it would be important to approach the importance of these processes on the magnitude of wealth effects, an aspect that is analyzed in a recent work of Boone et al. (2001).

It would be also important to analyze the importance of the concentrated nature of the wealth on the verification of modest wealth effects and the impact of that nature on the dynamics of wealth distribution.

Finally, although literature emphasizes the role played by stock market on nondurable consumption expenditure, it would also be important to analyze the role played by these markets on durables consumption expenditure.

\section{References}

ANDO, A.; MODIGLIANI, F. (1963), "The 'Life Cycle' Hypothesis of Saving: Aggregate Implications and Tests", American Economic Review, 53, 55-84.

ARENA, J. (1965), "Postwar stock market changes and consumer spending", The Review of Economic and Statistics, 47, 379-91.

ATTANASIO, O. (1998), "Consumption demand", National Bureau of Economic Research Working Paper \#6466.

BARRELL, R.; IN'T VELD, J. (1992), "Wealth effects and fiscal policy in the National Institute Global Econometric Model”, National Institute Economic Review, May, issue $140,78-85$.

BAYOUMI, T. (1993), "Financial deregulation and household saving", The Economic Journal, 103(421), 1432-1443.

BEKAERT, G.; HARVEY, C.; LUNDBLAD, C. (2001), "Does financial liberalization spur growth?”, National Bureau of Economic Research Working Paper \#8245.

BERTAUT, C.; STARR-McCLUER, M. (2000), "Household portfolios in the United States", Board of Governors of the Federal Reserve System, Finance and Economics Discussion Papers \#2000-26.

BHATIA, K. (1972), "Capital gains and the aggregate consumption function", American Economic Review, 62(5), 866-879.

BLANCHARD, O.; CHOURAQUI, J.; HAGERMAN, R.; SARTOR, N. (1991), "The sustainability of fiscal policy: new answers to an old question”, NBER Reprints \#1547.

BLINDER, A.; DEATON, A. (1985), "The time-series consumption function revisited", Brookings Papers on Economic Activity: 2, 465-511. 
BONNER, X.; DUBOIS, E. (1995), "Peut-on comprendre la hausse imprévue du taux d'épargne des ménages depuis 1990?", Ministère de l'Economie, Economie et Prévisions, 121.

BONSER-NEAL, C.; DEWENTER, K. (1999), "Does financial market development stimulate savings? Evidence from emerging stock markets", Contemporary Economic Policy, 17(3), 370-380.

BOONE, L.; GIROUARD, N.; WANNER, I. (2001), "Financial liberalization, wealth and consumption", OECD, Economics Department Working Papers \#308.

BOONE, L.; GIORNO, C.; RICHARDSON, P. (1998), "Stock market fluctuations and consumption behaviour: some recent evidence", OECD Economics Department Working Papers \#208.

BOSWORTH, B. (1975), "The stock market and the economy", Brookings Papers on Economic Activity: 2, 257-290.

BRAYTON, F.; TINSLEY, P. (1996), “A guide to FRB/US”, Board of Governors of the Federal Reserve System, Finance and Economics Discussion Papers \#1996-42.

CAMPBELL, J. (1987), "Does saving anticipate declining labour income? An alternative test of the permanent income hypothesis", Econometrica, 55(6), 1249-1273.

CAPORALE, G.; WILLIAMS, G. (1997), "Revisiting Forward Looking Consumption and Financial Liberalisation in the United Kingdom", London Business School Discussion Papers \#20-97.

CASE, K.; QUIGLEY, J.; SHILLER, R. (2001), "Comparing wealth effects: the stock market versus the housing market", Cowles Foundation Discussion Paper \#1335.

CHENG, I.; FRENCH, E. (2000), "The effect of the run up in the stock market on labor supply", Federal Reserve Bank of Chicago Economic Perspectives, $4^{\text {th }}$ Quarter, 48-65.

DAVIDSON, J.; HENDRY, D. (1981), "Interpreting econometric evidence: the behavior of consumers' expenditure in the UK", European Economic Review, 16(1), 177-192.

DAVIS, M.; PALUMBO, M. (2001), "A primer on the economics and time-series econometrics of wealth effects", Board of Governors of the Federal Reserve System, Finance and Economics Discussion Papers \#2001-09.

DESNOYERS, Y. (2001), "L'effet de la richesse sur la consommation aux Etats-Unis, Banque du Canada, Document de Travail \#2001-14.

DYNAN, K.; MAKI, D. (2001), “Does stock market wealth matter for Consumption?", Board of Governors of the Federal Reserve System, Finance and Economics Discussion Papers \#2001-23.

ELLIOTT, J. (1980), "Wealth and wealth proxies in a permanent income model", The Quarterly Journal of Economics, 95(3), 509-535. 
ENGLE, R.; GRANGER, C. (1987), "Co-integration and error-correction: representation, estimation and testing”, Econometrica, 55(2), 251-276.

EVANS, M. (1967), "The importance of wealth in the consumption function", The Journal of Political Economy, 75(1), 335-351.

FLAVIN, M. (1981), "The adjustment of consumption to changing expectations about future income", The Journal of Political Economy, 89(5), 974-1009.

FRIEDMAN, M. (1957), A theory of the consumption function, Princeton University Press, Princeton.

GRUNSPAN, T.; SICSIC, P. (1997), "Les effets de richesse", Conseil National du Crédit et du Titre, Rapport annuel, 187-192.

HALL, R. (1988), "Intertemporal substitution in consumption", The Journal of Political Economy, Vol. 96(2), 339-357.

HALL, R. (1978), "Stochastic implications of the life cycle-permanent income hypothesis: theory and evidence", The Journal of Political Economy, Vol. 86(6), 971987.

HARRIS, R. (1995), Using cointegration analysis in econometric modeling, Prentice Hall, Hertfordshire.

HORIOKA, C. (1996), "Capital gains in Japan: their magnitude and impact on consumption”, The Economic Journal, 106(436), 560-577.

LANTZ, C.; SARTRE, P. (2001), "Consumption, savings, and the meaning of the wealth effect in general equilibrium", Federal Reserve Bank of Richmond Economic Quarterly, 87(3), 53-71.

LAUMAS, G.; RAM, R. (1982), "Role of wealth in consumption: an empirical investigation", The Review of Economics and Statistics, 64(2), 204-210.

LUDVIGSON, S.; STEINDEL, C. (1999), "How important is the stock market effect on consumption?", Federal Reserve Bank of New York Economic Policy Review, 5(2), 2951.

MACKINNON, J. (1991), "Critical Values for Cointegration Tests" in ENGLE, R.; GRANGER, C., eds., Long-run Economic Relationships: Readings in Cointegration, Oxford University Press.

MACKLEM, T. (1994), "Wealth, disposable income and consumption: some evidence for Canada”, Banque du Canada, Rapport technique, 71.

MADDALA, G.; KIM, I. (1998), Unit roots, cointegration, and structural change, Cambridge University Press, Cambridge. 
MAKI, D.; PALUMBO, M. (2001), "Disentangling the wealth effect: a cohort analysis of household saving in the 1990s", Board of Governors of the Federal Reserve System, Finance and Economics Discussion Papers \#2001-21.

MANKIW, N.; ZELDES, S. (1991), "The consumption of stockholders and nonstockholders", Journal of Financial Economics, 29(1), 97-112.

MASSON, P.; BAYOUMI, T.; SAMIEI, H. (1996), "International evidence on the determinants of saving", Center for Economic Policy Research Discussion Papers $\# 1368$.

MAYER, C.; SIMONS, K. (1994), "Reverse mortgages and the netity of housing wealth", Journal of the American Real Estate and Urban Economics, 22(2), 235-255.

MEHRA (2001), "The wealth effects in empirical life cycle aggregate consumption equations", Federal Reserve Bank of Richmond Quarterly Review, 87(2), 45-68.

MODIGLIANI, F. (1971), "Monetary policy and consumption", Consumer Spending and Monetary Policy: The Linkages, Federal Reserve Bank of Boston Conference Series, 5.

MODIGLIANI, F.; TARANTELLI, E. (1975), "The consumption function in a developing economy and the Italian experience", American Economic Review, 65(5), 825-842.

MUTOH, H.; KAWAI, H.; SANO, M. (1993), "Consumption and Adverse Wealth Effect", Nihon Keizei Kenkyu, 26, 57-92.

NEWEY, W.; WEST, K. (1987), “A simple positive semi-definite, heterokedasticity, and autocorrelation consistent covariance matrix", Econometrica, 55(3), 703-708.

OGAWA, K. (1992), "An Econometric Analysis of Japanese Households Behavior", Financial Review, 25, 112-134.

OGAWA, K.; KITASAKA, S.; YAMAOKA, H.; IWATA, Y. (1996), “An empirical reevaluation of wealth effect in Japanese household behavior", Japan and the World Economy, 8(4), 423-442.

OTOO, M. (1999), "Consumer sentiment and the stock market", Board of Governors of the Federal Reserve System, Finance and Economics Discussion Papers \#1999-60.

PEARCE, D. (1983), "Stock prices and the economy", Federal Reserve Bank of Kansas City Economic Review, 68(9), 7-22.

PICHETTE, L. (2000), "Les effets réels du cours des actions sur la consommation", Banque du Canada, Document de travail \#2000-21.

POTERBA, J. (2000), "Stock market wealth and consumption", Journal of Economic Perspectives, 14(2), 99-118. 
POTERBA, J.; SAMWICK, A. (1995), "Stock ownership patterns, stock market fluctuations, and consumption”, Brookings Papers on Economic Activity: 2, 295-372.

ROSSI N.; VISCO, I. (1995), "National saving and social security in Italy", Ricerche Economiche, 49(4), 329-356.

SAIKKONEN, P. (1991), "Asymptotically efficient estimation of cointegrating regressions", Economic Theory, 7(1), 1-21.

SCHWERT, G. (1989), "Tests for unit roots: a Monte Carlo investigation”, Journal of Business and Economic Statistics, 7(2), 147-159.

SHIRVANI, H.; WILBRATTE, B. (2002), "The wealth effect ot the stock market revisited", Journal of Applied Business Research, 18(2), 9-14.

SHIRVANI, H.; WILBRATTE, B. (2000), "Does consumption respond more strongly to stock market declines than to increases?", International Economic Journal, 14 (3), 41-49.

STARR-McCLUER, M. (2002), "Stock market wealth and consumer spending", Economic Inquiry, 40 (1), 69-79.

STOCK, J.; WATSON, M. (1993), "A simple estimator of cointegrating vectors in higher order integrated systems", Econometrica, 61(4), 783-820.

TAN, A.; VOSS, G. (2000), "Consumption and wealth", Reserve Bank of Australia Discussion Paper \#2000-09.

TOKUA, I. (2002), "The asset price effect on consumption: the U. S. case", Economic Review (Keizai Kenkyu), 53 (1), 64-78.

ZELDES, S. (1989), "Optimal consumption with stochastic income: deviations from certainty equivalence”, Quarterly Journal of Economics, 104(2), 275-298. 


\section{Annex I \\ Evolution of wealth's composition}

According to Flow of Funds Accounts, household and nonprofit organizations' net worth ${ }^{26}$ can be disaggregated in assets and liabilities. The assets include:

- tangible assets: real, software and equipment owned by nonprofit organizations and consumer durable goods;

- financial assets: deposits (foreign deposits, checkable deposits and currency, time and savings deposits and money market fund shares), credit market instruments (open market paper, U.S. government securities (Treasury savings bonds, other Treasury -, Agency), municipal securities, corporate and foreign bonds and mortgages), corporate equities, mutual fund shares, security credit, life insurance reserves, pension fund reserves, investment in bank personal trusts, equity in noncorportate business and miscellaneous assets.

The liabilities include:

- credit market instruments: home mortgages, consumer credit, municipal securities, bank loans n.e.c., other loans and advances and commercial mortgages;

- security credit;

- trade payables; and

- deferred and unpaid life insurance premiums.

The sum of assets less the sum of liabilities defines the net wealth (net worth) of households and nonprofit organizations.

When we look to the behavior of assets and liabilities, it is notorious the increasing tendency of their value, although the first is more pronounced that the last. We can also observe the acceleration of growth in the value of assets from the second half of the seventies to the middle of the nineties. However, after 1999, we assist to a deterioration of the value of total assets.

When we analyze the behavior of the assets by category, we can see that in the period 1952-2001, the financial assets show a more pronounced growth than tangible

\footnotetext{
${ }^{26}$ Sector includes farm households.
} 
assets, although the first show an inversion of the positive trend since 1999, a feature that can re related with the negative behavior of the stock markets.

When we analyze the behavior of tangible assets, we can see that real estate are the most important tangible asset, and its relative importance has been increasing over time - for the period 1952-1954, they represented one fourth of the tangible assets; in 2000, they represented more than $80 \%$. This fact can be connected with the strong appreciation of the residential market observed during the eighties. By its turn, the consumer durable goods have been loosing their relative importance. Finally, the software and equipment owned by nonprofit organizations represent a marginal importance of tangible assets.

Tangible assets' categories - Relative importance (\%)

\begin{tabular}{c|c|c|c}
\hline & $\begin{array}{c}\text { Real } \\
\text { Period }\end{array}$ & $\begin{array}{c}\text { Equipment and software } \\
\text { owned by }\end{array}$ & $\begin{array}{c}\text { Consumer durable } \\
\text { Goods }^{28}\end{array}$ \\
\hline $1952-1954$ & 73.64 & 0.34 & 26.02 \\
$1955-1959$ & 74.49 & 0.41 & 25.10 \\
$1960-1964$ & 75.83 & 0.46 & 23.71 \\
$1965-1969$ & 75.27 & 0.48 & 24.25 \\
$1970-1974$ & 75.64 & 0.51 & 23.85 \\
$1975-1979$ & 76.23 & 0.64 & 23.13 \\
$1980-1984$ & 78.58 & 0.61 & 20.81 \\
$1985-1989$ & 79.78 & 0.56 & 19.66 \\
$1990-1994$ & 79.11 & 0.72 & 20.17 \\
$1995-1999$ & 79.63 & 0.76 & 19.61 \\
2000 & 80.86 & 0.76 & 18.38 \\
$2001: Q 4$ & 81.38 & 0.74 & 17.88 \\
\hline
\end{tabular}

Source: Flow of Funds Accounts, Board of Governors of Federal Reserve System; author's calculus.

When we analyze the behavior of financial assets, we can emphasize that:

- the deposits, which represented in the fifties approximately $17 \%$ of the financial assets, lost relative importance since the eighties to approximately $14 \%$;

- the credit market instruments lost their relative importance $(12 \%$ in the beginning of the fifties to less than half in 2001);

- the corporate equities, which represented in the sixties almost $30 \%$ of the financial assets, lost importance till the eighties (a value close to 12\%), but have increased their importance during nine ties (to a value close to 20\%);

\footnotetext{
${ }_{27}$ At replacement (current) cost.

${ }^{28}$ Value based on the market values of equities held and the book value of other assets held by mutual funds.
} 
- the mutual fund shares, which represented a marginal importance of financial assets in the fifties (less than 1\%), increased their relative importance $\mathrm{b}$ a value close to $10 \%$; on the opposite, the life insurance reserves lost importance;

- the notorious growth of the pension fund reserves that in the fifties represented approximately 5\% of the financial assets and since the second half of the nineties represent more than one fourth of those assets and are actually the most important financial asset in U.S.A.;

- finally, the equities in noncorporate business, which in the first half of the fifties represented almost $40 \%$ of the financial assets, significantly lost their importance during the nineties to approximately $15 \%$.

When we observe the behavior of the liabilities, we must emphasize that:

- the credit market instruments represent the main component, deserving reference:

$\circ$ the fact that mortgages represent almost two thirds of the total liabilities;

○ the fact that consumer credit lost its importance $(30 \%$ in the first half of the fifties; almost $20 \%$ in the second half of the nineties);

- the other components of liabilities have a marginal relative importance during the considered period. 
Financial assets' categories - relative importance $(\%)$

\begin{tabular}{|c|c|c|c|c|c|c|c|c|c|c|}
\hline Period & Deposits & \begin{tabular}{|c|} 
Credit market \\
instruemnts
\end{tabular} & $\begin{array}{l}\text { Corporate } \\
\text { equities }^{29}\end{array}$ & $\begin{array}{c}\text { Mutual fund } \\
\text { shares }^{30}\end{array}$ & $\begin{array}{c}\text { Security } \\
\text { credit }\end{array}$ & $\begin{array}{c}\text { Life } \\
\text { insurance } \\
\text { reserves }\end{array}$ & $\begin{array}{l}\text { Pension } \\
\text { fund } \\
\text { reserves }\end{array}$ & $\begin{array}{c}\text { Investment } \\
\text { in bank } \\
\text { personal } \\
\text { trusts } \\
\end{array}$ & $\begin{array}{c}\text { Equity in } \\
\text { noncorporate } \\
\text { business }\end{array}$ & $\begin{array}{c}\text { Miscellaneous } \\
\text { assets }\end{array}$ \\
\hline $1952-1954$ & 17.46 & 12.37 & 18.83 & 0.54 & 0.09 & 7.28 & 4.41 & 0.00 & 37.81 & 1.21 \\
\hline 1955-1959 & 17.11 & 11.33 & 24.97 & 0.93 & 0.08 & 6.59 & 5.78 & 0.00 & 32.16 & 1.05 \\
\hline $1960-1964$ & 18.01 & 10.10 & 28.47 & 1.44 & 0.08 & 5.91 & 7.43 & 0.00 & 27.63 & 0.92 \\
\hline 1965-1969 & 19.38 & 8.79 & 29.05 & 1.80 & 0.20 & 5.18 & 8.72 & 1.09 & 24.91 & 0.90 \\
\hline $1970-1974$ & 22.24 & 7.26 & 19.85 & 1.36 & 0.15 & 4.73 & 10.57 & 5.31 & 27.49 & 1.03 \\
\hline $1975-1979$ & 24.29 & 6.81 & 12.64 & 0.79 & 0.15 & 4.10 & 13.19 & 4.32 & 32.58 & 1.14 \\
\hline $1980-1984$ & 24.46 & 6.84 & 11.21 & 0.86 & 0.24 & 3.10 & 16.86 & 3.83 & 31.45 & 1.16 \\
\hline 1985-1989 & 23.81 & 8.69 & 11.83 & 2.89 & 0.35 & 2.58 & 21.21 & 3.75 & 23.48 & 1.41 \\
\hline $1990-1994$ & 18.82 & 9.91 & 15.63 & 4.23 & 0.50 & 2.63 & 24.20 & 3.78 & 18.84 & 1.46 \\
\hline 1995-1999 & 13.60 & 7.51 & 22.53 & 7.05 & 0.78 & 2.44 & 26.46 & 3.47 & 15.02 & 1.15 \\
\hline 2000 & 13.73 & 5.97 & 21.25 & 9.18 & 1.23 & 2.47 & 27.32 & 3.08 & 14.74 & 1.02 \\
\hline 2001:Q4 & 15.47 & 5.90 & 18.17 & 9.33 & 1.38 & 2.70 & 27.18 & 2.84 & 15.91 & 1.12 \\
\hline
\end{tabular}

Source: Flow of Funds Accounts, Board of Governors of Federal Reserve System; author's calculus.

\footnotetext{
${ }^{29}$ At market value.

${ }^{30}$ Value based on the market values of equities held and the book value of other assets held by mutual funds.

${ }^{31}$ Owner's equity in noncorporate business, farm business, and unincorporated security brokers and dealers.
} 
Liabilities' categories - relative importance $(\%)$

\begin{tabular}{|c|c|c|c|c|c|c|c|c|c|}
\hline \multicolumn{7}{|c|}{ Credit market instruments } & \multirow[b]{2}{*}{$\begin{array}{l}\text { Security } \\
\text { credit } \\
\end{array}$} & \multirow[b]{2}{*}{$\begin{array}{c}\text { Trade } \\
\text { payables }^{35} \\
\end{array}$} & \multirow[b]{2}{*}{$\begin{array}{l}\text { Deferred and unpaid } \\
\text { life insurance premiums }\end{array}$} \\
\hline Period & Home mortages ${ }^{32}$ & Consumer credit & Municipal securities ${ }^{3}$ & 3 Bank loans n.e.c. & Other loans and advances & Commercial mortgages ${ }^{34}$ & & & \\
\hline 1952-1954 & 60.23 & 30.73 & 0.00 & 0.30 & 2.86 & 1.87 & 1.77 & 1.11 & 1.14 \\
\hline 1955-1959 & 62.41 & 28.57 & 0.00 & 0.76 & 2.56 & 1.75 & 1.89 & 0.99 & 1.06 \\
\hline 1960-1964 & 63.19 & 26.79 & 0.00 & 1.16 & 2.87 & 2.16 & 1.80 & 1.01 & 1.01 \\
\hline 1965-1969 & 61.39 & 27.64 & 0.00 & 1.48 & 3.37 & 2.02 & 1.98 & 1.14 & 0.98 \\
\hline 1970-1974 & 59.67 & 28.59 & 0.05 & 1.61 & 4.15 & 1.96 & 1.57 & 1.38 & 1.02 \\
\hline 1980-1984 & 63.21 & 24.40 & 1.82 & 1.85 & 4.04 & 1.20 & 1.64 & 0.98 & 0.88 \\
\hline 1985-1989 & 64.01 & 24.09 & 2.81 & 1.03 & 2.97 & 1.67 & 1.67 & 1.22 & 0.53 \\
\hline 1990-1994 & 68.28 & 20.15 & 2.20 & 0.54 & 2.80 & 2.32 & 1.40 & 1.92 & 0.39 \\
\hline 1995-1999 & 65.90 & 21.58 & 1.97 & 1.09 & 3.20 & 1.71 & 2.25 & 1.99 & 0.31 \\
\hline 2000 & 65.94 & 21.01 & 1.92 & 0.99 & 3.30 & 1.58 & 3.13 & 1.86 & 0.26 \\
\hline 2001:Q4 & 67.18 & 20.89 & 1.90 & 0.71 & 3.27 & 1.61 & 2.41 & 1.79 & 0.24 \\
\hline
\end{tabular}

Source: Flow of Funds Accounts, Board of Governors of Federal Reserve System; author's calculus.

\footnotetext{
${ }^{32}$ Includes loans made under home equity lines of credit and home equity loans secured by junior liens..

${ }^{33}$ Liabilities of nonprofit organizations.

${ }^{34}$ Liabilities of nonprofit organizations.

${ }^{35}$ Liabilities of nonprofit organizations.
} 
In sum, the data reveal that the composition of financial assets has significantly changed, with the decreasing of the relative importance of savings deposits and the increasing of the relative importance of pension fund reserves, corporate equities and mutual fund shares. We should emphasize: the sustained growth of the prices of stocks in this period; the increasing number of mutual fund shares; the introduction of the pension fund reserves; the combination of higher prices of stocks and the increasing participation of the detention of stocks, through mutual fund shares and pension fund reserves, has led to a significant relative importance of stocks in the composition of financial assets..

We can also see that financial assets are the major asset of net wealth (almost $70 \%$ ) - in 1999, these assets represented more than $83 \%$ of net wealth. This importance has substantially increased during the nineties. The behavior of the tangible assets is opposite, representing in 1999, only $33 \%$ of net wealth. Finally, the liabilities represented in 1952 approximately $8 \%$ of net wealth; in the second quarter of 2001, they represent almost $19 \%$.

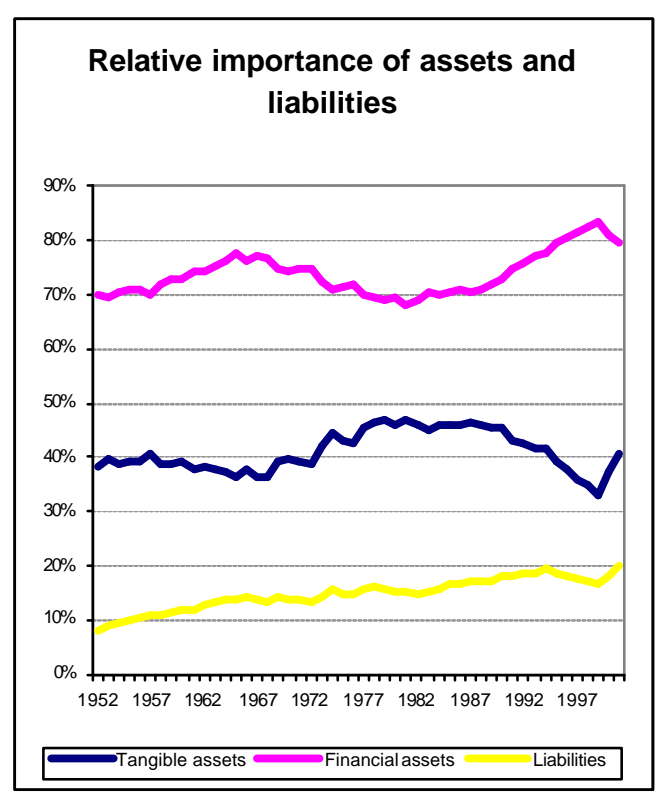

Source: Flow of Funds Accounts, Board of Governors of Federal Reserve System; author's calculus. 


\section{Annex II}

\section{Technical description of the variables used in the estimation of}

\section{models}

\section{Consumption}

Consumption is defined as the expenditure in non-durable consumption goods and services. Data are quarterly, seasonally adjusted at an annual rate, measured in billions of dollars (1996 prices), in per capita and expressed in the logarithmic form. Series comprises the period 1947:Q1-2001:Q4. The source is U.S. Department of Commerce, Bureau of Economic Analysis, Table 2.2..

\section{Wealth}

Aggregate wealth is defined as the net worth of households and nonprofit organizations. Data are quarterly, seasonally adjusted at an annual rate, measured in billions of dollars (1996 prices), in per capita and expressed in the logarithmic form. Series comprises the period 1952:Q2-2001:Q4. The source of information is Flow of Funds Accounts, Board of Governors of Federal Reserve System, Table B.100, line 43.

\section{Stock-market wealth}

Stock market wealth is defined as the sum of value of stocks, directly and indirectly held, namely: (a) stocks held by households - direct property (line 24 of Table B.100); (b) stocks held by private pension funds (line 14 of Table L.119); (c) stocks held by state and local government retirement funds (line 13 of Table L.120); (d) stocks held by bank personal trusts and e estates (line 14 of Table L.116); (e) stocks held by closed-end funds (line 6 of Table L.123); (f) stocks held by mutual funds (line 10 of Table L.122); and (g) stocks held by life insurance companies (line 13 of Table L.117), multiplied by the ratio of reserves of life insurance companies (lines 18 and 19 of Table L.117) to the total final assets of life insurance companies (line 1 of Table L.117). This definition follows Davis e Palumbo (2001). Data are quarterly, seasonally adjusted at an annual rate, measured in billions of dollars (1996 prices), in per capita and expressed in the logarithmic form. Series comprises the period 1952:Q2-2001:Q4. The source of 
information is Flow of Funds Accounts, Board of Governors of Federal Reserve System.

\section{Stock-market wealth, directly held}

Stock market wealth (directly held) is defined as the sum of value of stocks held by households (line 24 of Table B.100). Data are quarterly, seasonally adjusted at an annual rate, measured in billions of dollars (1996 prices), in per capita and expressed in the logarithmic form. Series comprises the period 1952:Q2-2001:Q4. The source of information is Flow of Funds Accounts, Board of Governors of Federal Reserve System.

\section{Stock-market wealth, indirectly held}

Stock market wealth (indirectly held) is defined as the sum of value of: (a) stocks held by private pension funds (line 14 of Table L.119); (b) stocks held by state and local government retirement funds (line 13 of Table L.120); (c) stocks held by bank personal trusts and e estates (line 14 of Table L.116); (d) stocks held by closed-end funds (line 6 of Table L.123); (e) stocks held by mutual funds (line 10 of Table L.122); and (f) stocks held by life insurance companies (line 13 of Table L.117), multiplied by the ratio of reserves of life insurance companies (lines 18 and 19 of Table L.117) to the total final assets of life insurance companies (line 1 of Table L.117). Data are quarterly, seasonally adjusted at an annual rate, measured in billions of dollars (1996 prices), in per capita and expressed in the logarithmic form. Series comprises the period 1952:Q22001:Q4. The source of information is Flow of Funds Accounts, Board of Governors of Federal Reserve System.

\section{Non-stock market wealth}

Non-Stock market wealth is defined as the difference between aggregate net wealth, held by households and nonprofit organizations (line 43 of Table B.100) and stock market wealth (see previous definition). This definition follows Davis e Palumbo (2001). Data are quarterly, seasonally adjusted at an annual rate, measured in billions of dollars (1996 prices), in per capita and expressed in the logarithmic form. Series comprises the period 1952:Q2-2001:Q4. The source of information is Flow of Funds Accounts, Board of Governors of Federal Reserve System. 


\section{After-tax labor income}

After-tax labor income is defined as the sum of wages and salaries, transfer payments, and other labor income, subtracted by personal contributions for social insurance and taxes. Taxes are defined as: [(wages and salaries) / (wages and salaries + proprietor' income with inventory valuation and capital consumption adjustments + rental income + personal dividends + personal interest income)] $\mathrm{x}$ (personal tax and non-tax payments). Data are quarterly, measured in billions of dollars (1996 prices), in per capita and expressed in the logarithmic form. Series comprises the period 1947:Q1-2001:Q4. The source of information is U.S. Department of Commerce, Bureau of Economic Analysis, Table 2.1..

\section{Population}

Population was defined by dividing aggregate real disposable income by per capita disposable income. Data are quarterly. Series comprises the period 1946:Q1-2001:Q4. The source of information is U.S. Department of Commerce, Bureau of Economic Analysis, Table 2.1..

\section{Price Deflator}

The nominal after-tax income, wealth and interest rates were deflated by the personal consumption expenditure chain-type price deflator $(1996=100)$, seasonally adjusted. Data are quarterly. Series comprises the period 1947:Q1-2001:Q4. The source of information is U.S. Department of Commerce, Bureau of Economic Analysis, Table 7.4..

\section{Inflation rate}

Inflation rate was computed from price deflator. Data are quarterly. Series comprises the period 1947:Q2-2001:Q4. The source of information is U.S. Department of Commerce, Bureau of Economic Analysis, Table 7.4.

\section{Unemployment rate}

Unemployment rate was defined as the civilian unemployment rate. Quarterly unemployment rate was computed as the simple arithmetic average of the values observed in three consecutive months. Series comprises the period 1948:Q1-2001:Q4 and the source of information is U.S. Department of Labor, Bureau of Labor Statistics. 


\section{Interest rate}

We use two measures for the interest rate: 3-month U.S. Treasury bills real interest rate and real interest rate of mortgages. In both cases, original data is monthly and we convert them to a quarterly periodicity by computing the simple arithmetic average of three consecutive months. Additionally, we computed real interest rates as the difference between nominal interest rates and the inflation rate. The 3-month U.S. Treasury bills real interest rate' series comprises the period 1952:Q1-2001:Q4, and the source of information is the H.15 publication of the Board of Governors of the Federal Reserve System. Data comprises the period 1971:Q4-2001:Q4 and the source of information is the Federal Home Mortgage Corporation.

\section{Consumer sentiment index}

We use the consumer sentiment index $(1960: \mathrm{M} 1=100)$ provided by the Survey Research Center of the Universidade of Michigan, through the Surveys of Consumers. Original data is monthly and was converted to a quarterly basis by computing the simple arithmetic average of three consecutive months. Series comprises the period 1960:Q12001:Q4.

\section{Budget surplus}

Budget surplus was defined as the Federal Government surplus. Data are quarterly, in billions of dollars and in per capita terms, and we use the public expenditure chain-type price deflator $(1996=100)$. Data are not seasonally adjusted. Series comprises the period 1968:Q1-2001:Q4 and the source of information is U.S. Department of Commerce, Bureau of Economic Analysis, Table 3.18B.

\section{Balance on Current Account}

Data are quarterly, in billions of dollars, in per capita terms and we use consumption deflator $(1996=100)$. Data was seasonally adjusted at annual rates. Series comprises the period 1960:Q1-2001:Q4, and the source of information is U.S. Department of Commerce, Bureau of Economic Analysis.

\section{Rate of growth of GDP}

Data are quarterly, seasonally adjusted at annual rates, and the eries comprises the period 1947:Q2-2001:Q4. The source of information is U.S. Department of Commerce, Bureau of Economic Analysis, Table 8.2.. 